\title{
MOLECULAR AND BIOPHYSICAL MECHANISMS REGULATING HYPERTROPHIC DIFFERENTIATION IN CHONDROCYTES AND MESENCHYMAL STEM CELLS
}

\author{
Deborah Studer ${ }^{1,2}$, Christopher Millan ${ }^{1}$, Ece Öztürk ${ }^{1}$, Katharina Maniura-Weber ${ }^{2}$ and Marcy Zenobi-Wong ${ }^{1, *}$ \\ ${ }^{1}$ Cartilage Engineering + Regeneration Laboratory, Department of Health, Science and Technology, \\ ETH Zürich, Switzerland \\ ${ }^{2}$ Laboratory for Materials-Biology Interactions, Empa, \\ Swiss Federal Laboratories for Materials Testing and Research, St. Gallen, Switzerland
}

\begin{abstract}
Chondrocyte hypertrophy is one of the key physiological processes involved in the longitudinal growth of long bones, yet regulation of hypertrophy is becoming increasingly relevant for clinical application of mesenchymal stem cells (MSCs) and screening for drugs to treat hypertrophic osteoarthritis. The extraordinary cell volume increase during hypertrophy is accompanied by an up-regulation of collagen X, matrix metalloproteinases (MMPs), and vascular endothelial growth factor (VEGF), all which are targets of the runt-related transcription factor 2 (Runx2). Many pathways, including parathyroid hormone-related protein (PTHrP)/Indian Hedgehog, Wingless/Int (Wnt)/ $\beta$ catenin, and transforming growth factor beta (TGF- $\beta$ )/ Sma and Mad Related Family (Smad) pathways, can regulate hypertrophy, but factors as diverse as hypoxia, coculture, epigenetics and biomaterial composition can also potently affect Runx 2 expression. Control of hypertrophic differentiation can be exploited both for cartilage repair, where a stable phenotype is desired, but also in bone regeneration, where hypertrophic cartilage could act as a template for endochondral bone formation. We hope this review will motivate the design of novel engineered microenvironments for skeletal regeneration applications.
\end{abstract}

Keywords: Hypertrophy; mesenchymal stem cells; chondrogenesis; biomaterials; epigenetics; hypoxia; coculture.

*Address for correspondence:

Marcy Zenobi-Wong

ETH Zürich

Cartilage Engineering and Regeneration

Gloriastrasse 35, ETZ F84

8092 Zürich, Switzerland

Telephone Number: +41446325089

E-Mail: zmarcy@ethz.ch

\section{Introduction}

Due to its avascular nature, cartilage tissue does not have access to the body's healing mechanisms and has a very low capacity for regeneration. Current clinical treatment of diseased or injured cartilage does not sufficiently restore long-term function and relieve joint pain. The material properties of native cartilage, which contains large quantities of collagen II fibrils for tensile strength and glycosaminoglycans (GAGs) such as aggrecan for osmotic swelling properties that confer compressive strength, have yet to be duplicated in vitro. Cartilage engineering, which has been the subject of many reviews (Hutmacher, 2000; Beris et al., 2005; Freed et al., 2006; Kuo et al., 2006; Nesic et al., 2006; Swieszkowski et al., 2007; Giannoni and Narcisi, 2009; Vinatier et al., 2009; Mauck and Burdick, 2011), presents numerous challenges. Isolation of chondrocytes from healthy joint tissue causes donor site morbidity. Further, 2D expansion of chondrocytes to achieve sufficient numbers of cells for transplantation results in loss of the chondrogenic phenotype at early passage (Benya and Shaffer, 1982). Mesenchymal stem cells (MSCs) could be a potentially suitable substitute as a cell source as they are present in large quantities in adipose tissue, bone marrow, synovium and cartilage (Williams et al., 2010) and can be expanded for a number of passages without losing their ability to undergo chondrogenic differentiation. Unfortunately, the phenotype of MSCs in cartilage repair is unstable so that differentiation continues along the endochondral ossification pathway (Sekiya et al., 2002; Pelttari et al., 2006). This review summarises the biomaterial, molecular, epigenetic and environmental conditions which regulate hypertrophy, with an aim to develop therapies to control MSCs in clinical applications or to target hypertrophic osteoarthritis.

\section{Chondrogenesis in the growth plate}

Many clues for controlling hypertrophy can be found following the process of skeletal development which begins in humans between 4 and 5 weeks after fertilisation (Holtzer, 1964; Reddi, 2000). Chondroprogenitor cells of diverse embryonic origin (Quintana et al., 2008) begin to up-regulate expression of transforming growth factor beta (TGF- $\beta$ ), fibronectin, N-CAM, and N-cadherin which initiates cell condensation and cartilage differentiation (Hall and Miyake, 2000) (Fig. 1a). The differentiation phase of stem cells towards chondrogenesis can be divided into distinct stages including cell attachment, proliferation/ differentiation and differentiation/hypertrophy (Mrugala et al., 2009). 
(a)
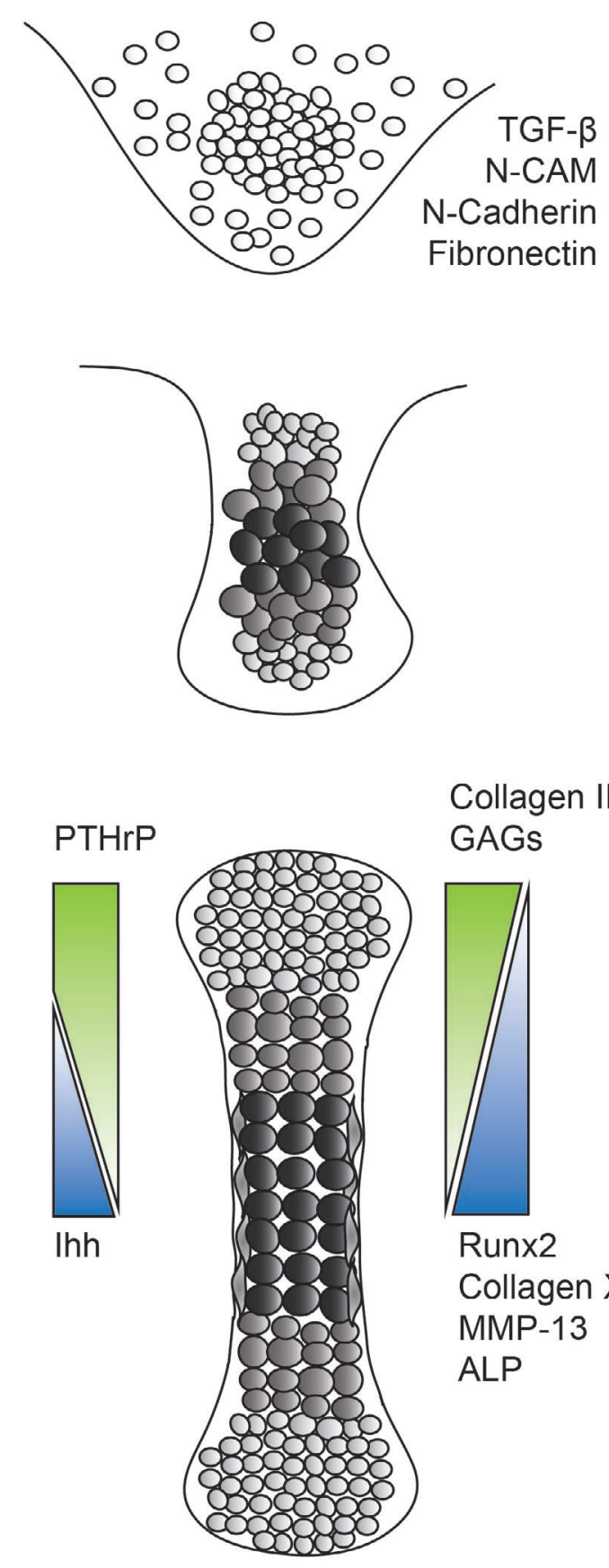
GAGs

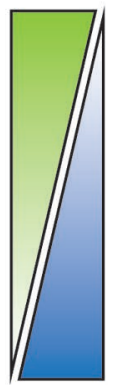

Runx2 MMP-13

ALP (b)

Collagen II

Collagen $X$
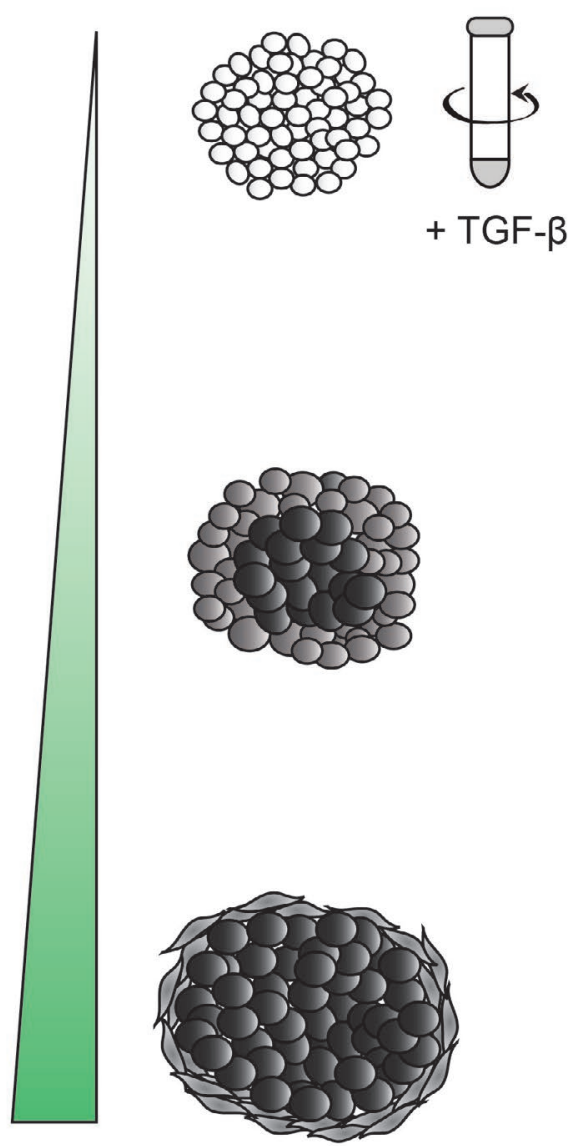

GAGs

Collagen II

Collagen $X$

MMP-13

Collagen I

\section{- MSC \\ - Chondrocyte \\ Pre-hypertrophic chondrocyte \\ - Hypertrophic chondrocyte \\ $\propto$ Fibroblast-like Cell}

Fig. 1. In vivo and in vitro chondrogenesis and hypertrophy. (a) Chondrogenesis initiates in limb bud development when MSCs undergo condensation, a process facilitated by increased expression of cAMP, TGF- $\beta$, fibronectin, $\mathrm{N}-\mathrm{CAM}$, and N-cadherin. Mature chondrocytes begin secreting cartilage matrix components primarily consisting of collagen II and glycosaminoglycans (GAGs). Chondrocytes outside the signalling range of PTHrP secreted by resting zone chondrocytes produce Ihh, a potent inducer of cell hypertrophy. Hypertrophic chondrocytes secrete collagen $\mathrm{X}$ which establishes the framework for subsequent calcification and endochondral ossification. (b) During in vitro chondrogenesis, MSCs are centrifuged into a micromass pellet and cultured in medium containing TGF- $\beta$ to induce differentiation. The critical spatiotemporal cues are not present in this method, and the majority of the MSC population continues to express both collagen II and collagen X concomitantly.

Chondrocyte hypertrophy is marked by a 10 -fold increase in cell volume (Bush et al., 2008), extracellular matrix remodelling (Fig. 2a) and expression of terminal differentiation markers including runt-related transcription factor 2 (Runx2), matrix metalloprotease 13 (MMP-13), collagen $\mathrm{X}$, alkaline phosphatase (ALP) and Indian Hedgehog (Ihh) (Mueller and Tuan, 2008) (Fig. 2b). The transcription factors Runx2 and myocyte enhancer 


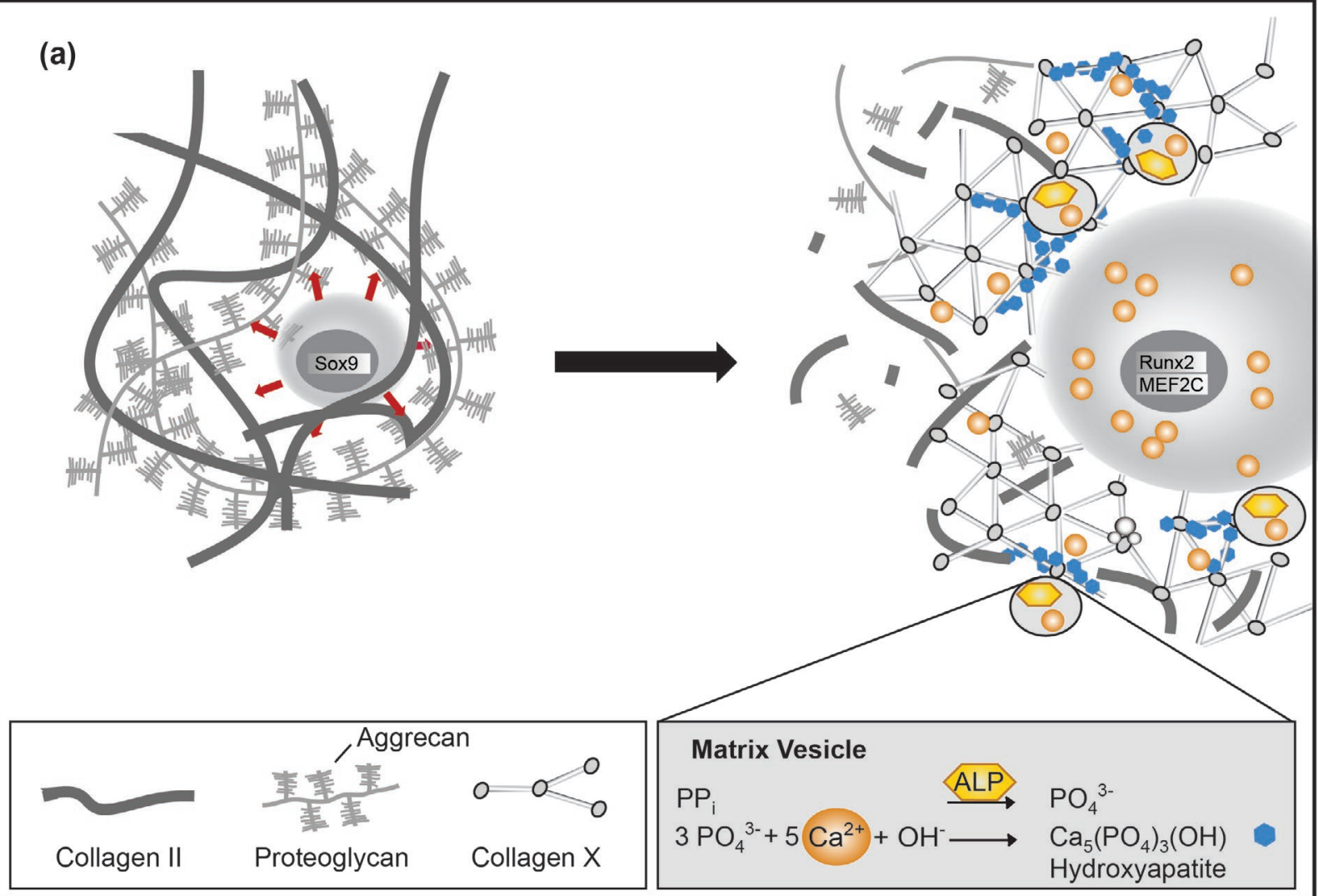

(b) Hypertrophy markers

Function

$\begin{array}{ll}\text { Runx2/MEF2C } & \text { Transcription of collagen X, Ihh, MMP-13, VEGF } \\ \text { MMP-13 } & \text { Degradation of collagen II and aggrecan } \\ \text { Collagen } X & \text { Regulation of matrix mineralization } \\ \text { ALP } & \text { Production of } \mathrm{PO}^{3-} \text { leading to mineralization } \\ \text { Ihh } & \text { Induction of proliferation of non-hypertrophic chondrocytes }\end{array}$

Fig. 2. Hypertrophy and the main actors. (a) Hypertrophy is marked by cell volume increase (red arrows) and ECM remodelling (b) These changes are regulated by the transcription factors Runx2/MEF2C, which regulate transcription of collagen X (Takeda et al., 2001; Stanton et al., 2004; Arnold et al., 2007), Ihh (Yoshida et al., 2004), MMP-13 (Shimizu et al., 2010) and VEGF (Kwon et al., 2011). MMP-13 degrades aggrecan and collagen II (Inada et al., 2004), Ihh increases non-hypertrophic chondrocyte proliferation (Van Donkelaar and Huiskes, 2007), collagen $X$ facilities the mineralisation process through association with matrix vesicles (MV) (Shen, 2005), and alkaline phosphatase (ALP) dephosphorylates pyrophosphate $\left(\mathrm{PP}_{\mathrm{i}}\right)$ to phosphate $\left(\mathrm{PO}_{4}^{3-}\right)$, leading to hydroxyapatite formation (Anderson, 2003).

factor-2C (MEF2C) drive the expression of the terminal differentiation markers including MMP-13 (Shimizu et al., 2010), collagen X (Takeda et al., 2001; Stanton et al., 2004; Arnold et al., 2007), Ihh (Yoshida et al., 2004) and vascular endothelial growth factor (VEGF) (Kwon et al., 2011), which all functionally contribute to endochondral ossification. Secreted MMP-13 degrades collagen II (Inada et al., 2004) and aggrecan (Fosang et al., 1996), key extracellular matrix (ECM) components of functional cartilage. Collagen $\mathrm{X}$ is deposited within the hypertrophic ECM and serves as a framework for subsequent calcification (Shen, 2005).
The large gradient of calcium concentration from a high extracellular to a lower intracellular concentration is most probably the major driving force of mineralisation, triggering the influx of calcium and subsequent volume increase (Bawden, 1989; Grandolfo et al., 1992). Calcification of the cartilage ECM originates at matrix vesicles (MVs) containing ALP, which are secreted from chondrocytes in response to increasing calcium concentrations (Iannotti et al., 1994) and are anchored to the collagen X matrix (Shen, 2005). In the first step of mineralisation, ALP hydrolyses pyrophosphate (PPi) to inorganic phosphate $\left(\mathrm{PO}_{4}^{3-}, \mathrm{Pi}\right)$ which, in the presence of 
calcium, forms hydroxyapatite inside the MVs (Balcerzak et al., 2003). Other sources of phosphate in MVs are the hydrolysis of phospholipids by PHOSPHO1 (Macrae et al., 2010) as well as the influx through the type-III Na/Pi cotransporter. Calcium influx into matrix vesicles is regulated by annexin II, V and VI with annexin V activity directly simulated by binding to collagen II and X fibrils (Kirsch, 2003). The second step of mineralisation is initiated by the penetration of hydroxyapatite crystals into the extracellular space where their prolongation is regulated by the $\mathrm{PO}_{4}^{3-}$ production by tissue non-specific alkaline phosphatase (TNAP) as well as PC-1, a nucleoside triphosphate pyrophosphohydrolase, inhibiting mineralisation through the production of PPi (Orimo, 2010).

The final stages of endochondral ossification, including degradation of the calcified matrix, VEGF-mediated vascular invasion of the calcified zone and deposition of osteoid on the calcified trabeculae by osteoblasts, are all under the control of MMPs (Ortega et al., 2004). Postmitotic hypertrophic chondrocytes pass through a transient autophagy stage to help meet the energy demands of cells (Srinivas et al., 2009) before undergoing apoptosis and removal from the growth plate (Shapiro et al., 2005).

\section{Biophysical changes during cell volume increase}

The explosive increase in the volume of the hypertrophic chondrocyte involves changes in intracellular and extracellular osmolarity, ECM degradation around the cell (Mackie et al., 2011), and an increase in the amount of organelles per cell. Osmotic swelling had been shown stereologically to be responsible for most of the cell volume increase (Buckwalter et al., 1986). Swelling can be the result of either an increase in cytoplasmic concentration or a decrease in extracellular osmolarity followed by aquaporin-mediated (Wang and Zhu, 2011) movement of water to re-establish iso-osmotic conditions. Ion concentration in the cell can be regulated by active transport across the cell membrane by the Na-K-Cl cotransporter (NKCC1) (Bush et al., 2010) and to a lesser degree by osmolite accumulation (Farnum et al., 2002). Although it is not completely understood if expression of terminal markers results in increased cell volume, or if the cell volume increase contributes to the expression of hypertrophic markers, it is clear that physical volume increase can affect cell function (Chao et al., 2006; Negoro et al., 2008; Clark et al., 2010) possibly through changes in the shape and size of the nucleus (Finan et al., 2009) and chromatin structure (Richter et al., 2007). Due to macromolecular crowding, even small changes in water content can have large influences on protein activity and interactions.

Of all the ECM molecules, aggrecan is the prime contributor to the osmotic pressure generated in cartilage, both due to its abundance and its high negative fixed charge. Although direct experimental evidence linking degraded ECM to increased cell volume is lacking, both the hypertrophic region of the growth plate (Hunziker et al., 1999) and the pericellular region surrounding hypertrophic osteoarthritic chondrocytes show decreases in GAG density. This weakening of the ECM could lead to higher cell volumes as the matrix is less able to counteract osmotic swelling forces.

\section{Chondrogenesis in vitro}

Chondrogenesis of MSCs is typically induced in vitro by incubation of cells in defined media containing TGF- $\beta$, ascorbic acid and dexamethasone in combination with a $3 \mathrm{D}$ culture system such as micromass pellets (Johnstone et al., 1998; Mackay et al., 1998; Mello and Tuan, 1999; Pittenger et al., 1999), hanging drop culture (Bohrnsen et al., 2009; Elvenes et al., 2009) or cellular encapsulation in hydrogels (Li et al., 2005; Mauck et al., 2006; Varghese et al., 2008; Liu et al., 2010; Bian et al., 2011b). While up-regulation of the chondrogenic genes Sox9 and collagen II can be observed during in vitro induction of chondrogenesis, the differentiating cells also exhibit markers of hypertrophy including collagen X, MMP-13, and ALP (Sekiya et al., 2002; Pelttari et al., 2006; Mueller and Tuan, 2008) (Fig. $1 b)$.

\section{Molecular Pathways of Hypertrophy}

PTHrP signalling (Fig. 3, yellow shading)

Parathryroid hormone-related protein (PTHrP) is emerging as one of the key anti-hypertrophy factors. The knockout of PTHrP (Vortkamp et al., 1996; Mak et al., 2008) or its receptor (Lanske et al., 1996; Guo et al., 2002; Kobayashi et al., 2002) leads to accelerated hypertrophy in vivo. PTHrP participates in a negative feedback loop with Indian Hedgehog (Ihh), a stimulatory factor of hypertrophy and chondrocyte proliferation (Lanske et al., 1996; Kobayashi et al., 2002; Kronenberg, 2006). Resting chondrocytes at the ends of long bones secrete PHTrP subsequently suppressing Ihh production in the proliferating zone. Chondrocytes outside of this paracrine signalling range, however, do produce Ihh and undergo hypertrophy (Fig. 1a). Ihh also leads to hypertrophy independently of PTHrP (Mak et al., 2008).

PTHrP functions by activating protein kinase A and C (PKA and PKC) (Li et al., 2004) and also interferes with the calcium pathway (see section "Calcium") by dephosphorylation of calcium/calmodulin-dependent protein kinase (CaMKII) (Li et al., 2011a). Cyclic adenosine monophosphate (cAMP)-dependent PKA phosphorylates Sox9 (Huang et al., 2000) and activates protein phosphatase II (PP2A) leading to the dephosphorylation of histone deacetylase 4 (HDAC4) and the inactivation of MEF2C (Kozhemyakina et al., 2009) (see sections "Transcription factors" and "Epigenetics"). PKC inhibits the activity of the mitogen-activated protein kinase (MAPK) p38 (Zhen et al., 2001) reducing MEF2C phosphorylation (Stanton et al., 2004) and, ultimately, hypertrophic gene expression.

In vitro studies with MSCs in pellet culture showed that PTHrP administration leads to suppression of hypertrophy but also down-regulates collagen II (Weiss et al., 2010). Conversely, Kim et al. (Kim et al., 2008) and Kafienah et al. (Kafienah et al., 2007) observed a selective hypertrophic inhibition upon PTHrP treatment with stable or even up-regulated expression of collagen II. This discrepancy 


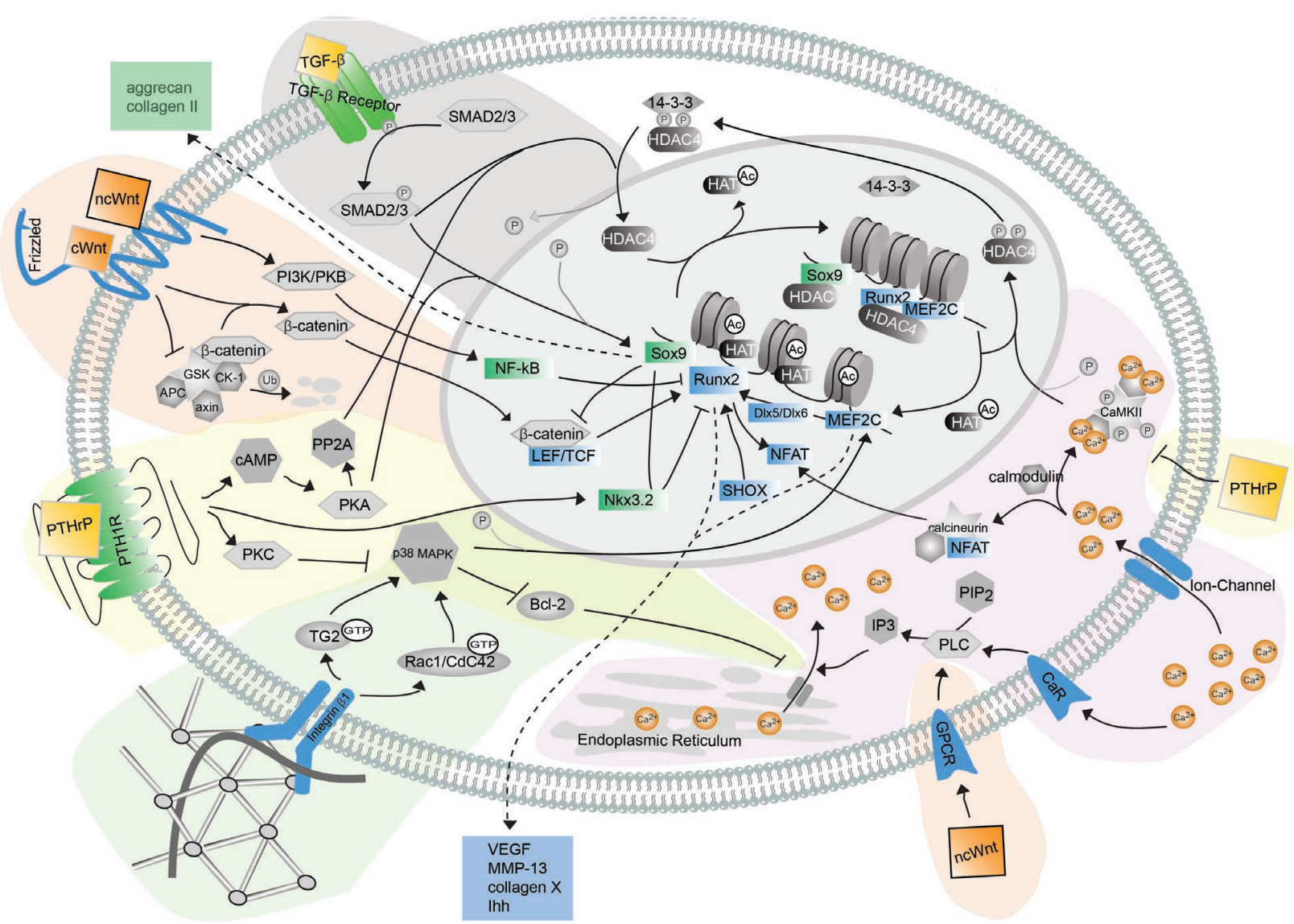

Fig. 3. Molecular pathways of chondrocyte hypertrophy. Signalling pathways initiated by TGF- $\beta$ (grey shading), PTHrP/PTH (yellow shading), Wnt (orange shading), integrin- $\beta 1$ interaction with collagen X (Luckman et al., 2003) (green shading) and calcium ions (pink shading). The main transcription factors (rectangular boxes) regulating hypertrophy are Sox9, which is responsible for the expression of collagen II and aggrecan, and Runx2 which regulates transcription of collagen X, MMP-13, VEGF and Ihh genes. Sox9 was shown to inhibit Runx2 (Dy et al., 2012) via Nkx3.2 (Yamashita et al., 2009; Zhou et al., 2006). MEF2C is proposed to be the main regulator of Runx2 (Arnold et al., 2007), which acts through Dlx5/Dlx6 (Verzi et al., 2007). SHOX/Shox2 is yet another upstream activator of Runx2. Nkx3.2 is induced by PTHrP (Provot et al., 2006) and acts synergistically with Sox9 (Yamashita et al., 2009) to inhibit Runx2 (Lengner et al., 2005). Ihh triggers the protein degradation of Nkx3.2 (Choi et al., 2012). Histone deacetylases (HDACs) participate in epigenetic regulation preventing transcription by stabilising DNA packing around histones (grey cylinders), whereas histone acetylases (HATs) provide access to the DNA strands. HDACs are released via phosphorylation by kinases that provide a phosphate $(\mathrm{P})$ which can then be bound by chaperones (14-3-3) and exported out of the nucleus.

Green colour indicates a pathway involved in the suppression and blue in the promotion of hypertrophy. Dashed lines represent the expression of marker genes. "P" depicts phosphorylation/dephosphorylation and "Ub" ubiquitination.

might be linked to the existence of both PTHrP receptor 1 (PTH1R)-dependent and PTH1R-independent pathways. PTH1R is not upregulated until day 21 of pellet culture in chondrogenic media (Mueller and Tuan, 2008; Weiss et al., 2010), whereas groups using bone morphogenetic protein 2 (BMP-2)-supplemented medium observed its up-regulation at day 0 (Hoffmann et al., 2002). PTH1R knockout mice showed accelerated hypertrophy and were unaffected by treatment with PTHrP, indicating that the inhibitory action on hypertrophy is dependent on PTH1R receptor binding (Lanske et al., 1996). The choice of the PTHrP isoform has further been shown to affect the suppressive action on hypertrophy with isoform 1-34 being the most effective in promotion of chondrogenesis as well as hypertrophy inhibition (Lee and Im, 2012).

\section{Calcium (Fig. 3, pink shading)}

The cytoplasmic and extracellular calcium concentration increases in growth plate chondrocytes between the reserve and hypertrophic zones (Iannotti and Brighton, 1989) where its presence is required for mineralisation. Calcium further acts inside the cell as a second messenger. This cytoplasmic calcium accumulation occurs through at least two distinct pathways. Extracellular $\mathrm{Ca}^{2+}$ can directly pass through ion channels in the cell membrane or alternatively it can activate G-protein coupled receptors (such as the calcium-sensing receptor $\mathrm{CaR}$, which is expressed in elevated levels in hypertrophic chondrocytes (Chang et al., 1999)) that stimulate intracellular $\mathrm{Ca}^{2+}$ release from the endoplasmic reticulum (ER) (Lamprecht and Lipkin, 2003; Hendy et al., 2009). The release from the ER is regulated by 
phospholipase C (PLC) activation, prompting hydrolysis of phosphatidylinositol 4,5-bisphosphate $\left(\mathrm{PIP}_{2}\right)$ to inositol 1,4,5-triphosphate ( $\left.\mathrm{IP}_{3}\right)$, which triggers the opening of ER ion-channels ( $\left.\mathrm{IP}_{3} \mathrm{R}\right)$ (D'Andrea et al., 2000). Which of the two accumulation pathways is primarily involved in hypertrophy remains a subject of debate (D'Andrea et al., 2000; Guilak et al., 1999; Wu et al., 2004).

Increase in extracellular calcium (Bonen and Schmid, 1991) and activity of CaR (Wu et al., 2004) were linked to collagen X up-regulation. Hypertrophic induction via this pathway is further regulated by calcium/calmodulindependent protein kinase (CaMKII) (Backs et al., 2008; Li et al., 2011a), which is activated by autophosphorylation upon binding of calcium to calmodulin. Activated CaMKII upregulates expression of hypertrophic genes (see "Epigenetics" section). PTHrP is also involved, inactivating CaMKII through dephosphorylation ( $\mathrm{Li}$ et al., 2011a). Calmodulin, in addition, binds and activates calcineurin leading to the dephosphorylation of nuclear factors of activated T-cells (NFATs). NFAT4 was shown to induce chondrogenesis of MSCs (Tomita et al., 2002) whereas NFATc2 was established as a downstream target of Runx2 involved in hypertrophy of MSCs (Thirunavukkarasu et al., 2007). Physiologic tonicity and the inhibition of calcineurin by the inhibitor FK506 decreased hypertrophic marker expression in osteoarthritic chondrocytes (van der Windt et al., 2012).

An interesting synergistic relationship exists between the inhibitory effect of PTHrP and the stimulatory effect of calcium on hypertrophy. $\mathrm{A} \mathrm{Ca}^{2+}$ sensitive sequence on the PTHrP promoter was identified, which highlights its calcium-dependent transcription (Zuscik et al., 2002). Administration of PTHrP or the overexpression of its receptor abolished the effect of elevated calcium to increase terminal differentiation markers (Rodriguez et al., 2005). Additionally, a feedback loop between PTH/PTHrP signalling and $\mathrm{Ca}^{2+}$ level has been established. PTH/PTHrP was shown to inhibit the activity of p38 mitogen-activated protein kinase (MAPK) (Zhen et al., 2001), which leads to an increase in B-cell lymphoma 2 (Bcl-2) activity, a known regulator of apoptosis, which was further shown to inhibit IP ${ }_{3} \mathrm{R}$ channel opening (Amling et al., 1997; He et al., 1997; Bassik et al., 2004). Despite the evidence of calcium depletion as an effective hypertrophy inhibitor in vivo, to our knowledge, there is no study applying a similar strategy to MSC chondrogenesis in vitro.

\section{TGF- $\boldsymbol{\beta}$ (Fig. 3, grey shading)}

Transforming growth factor- $\beta$ (TGF- $\beta$ ) is a potent inducer of chondrogenesis in vitro (Barry et al., 2001; Weiss et $a l ., 2010)$. Signalling pathways of the TGF- $\beta$ superfamily have been reviewed (van der Kraan et al., 2009) including its downstream phosphorylation of Sma and Mad Related Family (Smads), which exhibit both stimulatory and inhibitory effects on chondrocyte hypertrophy. The Smad1/5/8 route, through which BMPs signal and control FGF pathways (Yoon et al., 2006; Maruyama et al., 2010), induces hypertrophy by epigenetic changes (see section "Epigenetics") and blocking phosphorylation of Smad1/5/8 inhibited expression of 3 terminal differentiation markers (Hellingman et al., 2011). The Smad2/3 pathway is activated by TGF- $\beta$ directly leading to inhibition of hypertrophy and induction of chondrogenesis due to stabilisation of the Sox 9 transcription complex by Smad2/3 (Yang et al., 2001; Furumatsu et al., 2005). TGF- $\beta$ activation of Smad3 also leads to Runx 2 inhibition through epigenetic regulation (see "Epigenetics") (Kang et al., 2005). Though TGF- $\beta$ is clearly crucial in the regulation of chondrocyte hypertrophy, its addition to induction media during pellet culture of MSCs is not sufficient to suppress the onset of hypertrophy (Sekiya et al., 2002; Pelttari et al., 2006; Mueller and Tuan, 2008). TGF- $\beta 1$-supplemented expansion media has further shown to redirect chondrocytes towards hypertrophy (Narcisi et al., 2012).

\section{Wnt (Fig. 3, red shading)}

Activation of $\beta$-catenin by canonical Wingless/Int (Wnt) signalling is another pathway involved in regulation of chondrocyte hypertrophy. Wnt signalling controls the fate of $\beta$-catenin via the Frizzled receptor (Angers and Moon, 2009). In the absence of Wnt, $\beta$-catenin is bound by a degradation complex consisting of adenomatous polyposis coli (APD), axin, glycogen synthase kinase 3 (GSK3), and casein kinase $1 \alpha(\mathrm{CK}-1)$ which phosphorylate $\beta$-catenin initiating its ubiquitination and proteosomal degradation. Wnt activation of the Frizzled receptor interferes with the degradation complex and $\beta$-catenin can translocate to the nucleus where it binds to lymphoid enhancer factor (LEF) and $\mathrm{T}$ cell factor (TCF) proteins. The LEF/TCF/ $\beta$-catenin complex promotes Runx2-expression inducing hypertrophy (Dong et al., 2006). Sox9 inhibits this signalling through phosphorylation of $\beta$-catenin, marking it for degradation (Topol et al., 2009). The inhibition of canonical Wnt led to an increase in collagen II and aggrecan expression but did not affect collagen X expression in MSC pellet culture (Im et al., 2011).

The non-canonical Wnts (such as Wnt5a) exhibit dual functions during chondrogenesis of MSCs. At early stages, Wnt5a induces chondrogenesis and hypertrophy through intracellular calcium release via G-protein coupled receptor (GPCR) activation. Later, though, it can act as an inhibitor of hypertrophy by activating the phosphoinositide 3-kinase $(\mathrm{PI} 3 \mathrm{~K})$ /protein kinase B (PKB or Akt)-dependent pathway, which in-turn activates NF- $\mathrm{B}$ (nuclear factor kappa-lightchain-enhancer of activated B cells), an inhibitor of Runx2 (Bradley and Drissi, 2010).

\section{Integrin signalling (Fig. 3, green shading)}

The supporting matrix of chondrocytes is under constant remodelling to which cells respond by translating stimuli into intracellular signalling, a process mediated by integrin signalling (Millward-Sadler and Salter, 2004). Upon the exposure of a cell to ECM proteins, integrins cluster together and small Rho GTPases (RhoA, Rac1, CdC42) are activated regulating polymerisation and assembly of actin filaments which lead to the formation of focal adhesions and stress fibres (Amano et al., 1997).

The influence of RhoA/Rock on chondrogeneis and hypertrophy is somewhat controversial. Overexpression of RhoA/Rock was shown to suppress ALP and mineralisation in chondrocytes, whereas their counterparts, Rac1/CdC42 


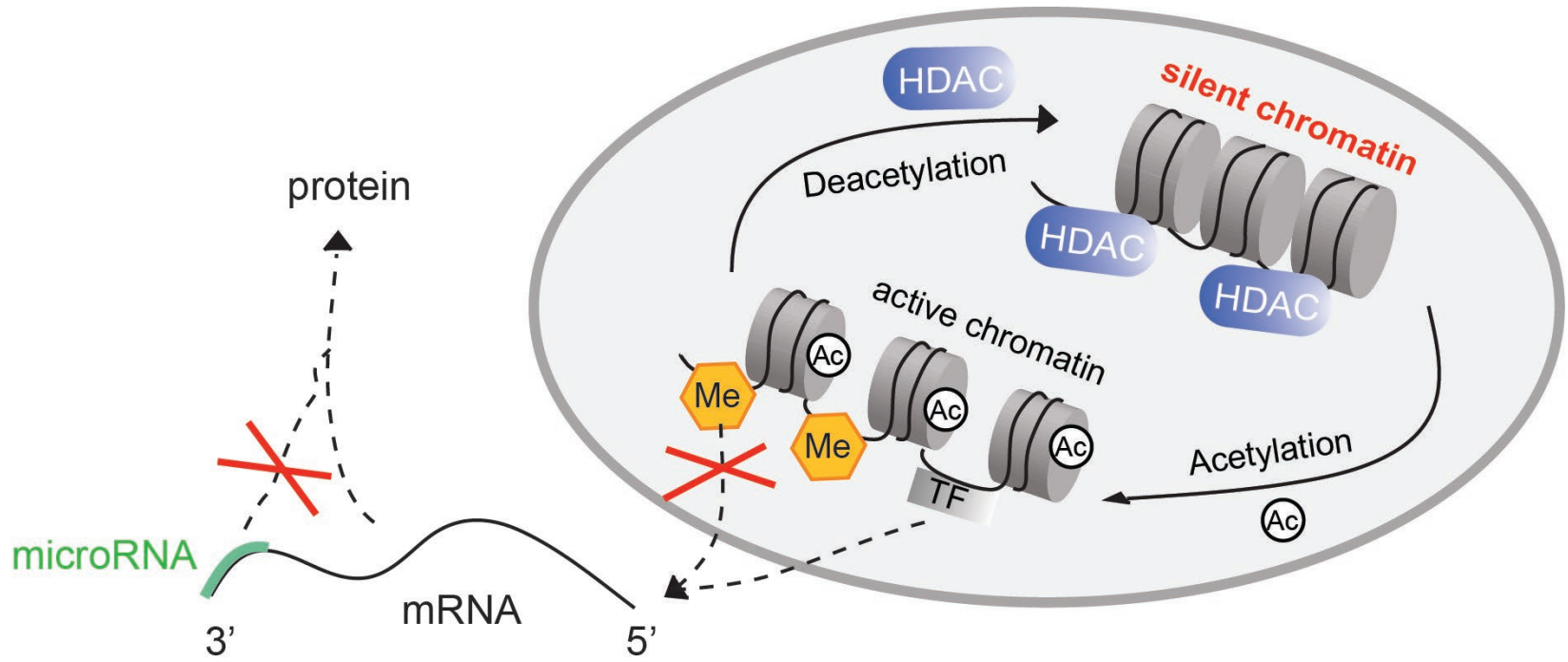

Fig. 4. The epigenetic regulation of hypertrophy involves histone deacetylases (HDACs), which act inside the nucleus to compact the chromatin into a "silent" structure. The acetylation (Ac) of histones opens up the chromatin for transcription of DNA by transcription factors (TF). Methylation (Me) of the DNA inhibits its transcription to messenger RNA (mRNA), whereas the post-transcriptional regulation of microRNAs inhibits the translation of mRNA by binding to its 3 ' untranslated region.

induced hypertrophy (Wang et al., 2004; Wang and Beier, 2005). Rock is also involved in the phosphorylation of Sox9 (Haudenschild et al., 2010). In contrast, downregulation of RhoA/Rock was shown to drive chondrogenic differentiation of mesenchymal stem cells by both inducing a round shape morphology (Loeser et al., 1995; Connelly et al., 2008; Lu et al., 2008) and by increasing Sox 9 activity (Woods and Beier, 2006). Rac1/CdC42 are activated by integrin- $\beta 1$, which also induces GTP-bound transglutaminase 2 (TG2) recruitment to the cell surface and phosphorylation of $\mathrm{p} 38 \mathrm{MAPK}$, which in turn activates MEF2C (Tanaka et al., 2007; Johnson et al., 2008). The inhibition of p38 MAPK effectively delayed hypertrophy in chondrocytes (Stanton et al., 2004). Blocking intergrin- $\beta 1$, a collagen II and X binding integrin (Loeser et al., 1995; Loeser et al., 2000; Luckman et al., 2003), was shown to be a successful strategy to suppress collagen X expression in chondrocytes and to decrease cell volume (Hirsch et al., 1997; Johnson et al., 2008).

\section{Epigenetics}

Histone (de)acetylation, DNA methylation and microRNAs are epigenetic events strongly involved in chondro-specific differentiation (Barter et al., 2012; Furumatsu and Ozaki, 2010) (Fig. 4). When DNA is present in the nucleus in a highly packed form wrapped around histones, access of transcription factors is restricted and transcription is consequently downregulated. Histone deactylases (HDACs) keep the chromatin in this form, whereas histone acetyl transferases (HATs) decrease the association of the histone with the DNA strand allowing the access of transcription factors. The release of HDACs from the histone complex is performed through kinase-induced phosphorylation, which creates chaperone docking sites (such as "14-3-3") docking sites that, once bound, transport HDACs out of the nucleus. Phosphatases dephosphorylate
HDACs to activate and relocate them into the nucleus. Another epigenetic control is the introduction of methylation sites on cytosine-guanine dinucleotides $(\mathrm{CpG})$ by DNA methyltransferases (Chen and Riggs, 2011). CpG islands (areas with high concentration of CpGs) are mostly found in the promoter region of genes where methylation causes gene silencing. MicroRNAs are post-transcriptional regulators of messenger RNAs (mRNAs) that, by binding to their complementary sequence, repress translation or lead to the degradation of mRNAs (Wienholds and Plasterk, 2005).

\section{Histone deacetylases}

HDAC4 is a potent regulator of chondrocyte hypertrophy. Adenoviral expression of HDAC4 in synovial-derived MSCs increased chondrogenesis as well as suppressed hypertrophy (Pei et al., 2009) by inhibiting Runx2 (Vega et al., 2004) and MEF2C (Wang et al., 1999). HDAC4 nuclear localisation is enhanced by TGF- $\beta$ and PTHrP, whereas increased calcium concentration and PTH lead to its phosphorylation and nuclear export. The transport of HDAC4 into the nucleus is initiated by TGF- $\beta$ through the activation of Smad3-complexes (Kang et al., 2005; Pei et al., 2009) and by PTHrP in a protein phosphatase II (PP2A)-dependent way (Kozhemyakina et al., 2009). PTH signals through PKA/cAMP to induce hypertrophy by escorting HDAC4 out of the nucleus (Shimizu et al., 2010). Besides PTH, an increased intracellular calcium concentration also leads to the phosphorylation of HDAC4 induced by the calcium-activated CaMKII (Backs et al., 2006). In addition to HDAC4, HDAC5 (Backs et al., 2008) and HDAC7 (Jensen et al., 2009) suppress MEF2C and Runx2 respectively.

\section{DNA methylation}

The role of gene silencing through DNA methylation during chondrogenesis and hypertrophy is still in its 
infancy in comparison to our knowledge of histone (de) acetylation. COL10A1, the gene encoding collagen $\mathrm{X} \alpha 1$, was found to be methylated in articular chondrocytes, whereas in mesenchymal stem cells this gene silencing was not identified (Zimmermann et al., 2008), This discrepancy may explain why hypertrophy is less likely in chondrocyte pellet cultures compared to MSC pellets. On the other hand, Runx2 and Sox 9 were shown to keep their methylation status during in vitro chondrogenesis of synovium-derived MSCs (Ezura et al., 2009). During osteoarthritis, the methylation of matrix metalloproteases present in healthy cartilage is lost. This de-methylation leads to the expression of MMP-3, -9, -13 and ADAMTS-4 (A Disintegrin And Metalloproteinase with Thrombospondin Motifs 4) (Roach et al., 2005; Cheung et al., 2009). The application of the unspecific de-methylating agent 5-aza-deoxycytidine on chondrogenic differentiation has yielded mixed results, where both increased osteogenesis (El-Serafi et al., 2011) and chondrogenesis (Caporali, 2011) have been found.

\section{MicroRNA}

MicroRNAs (miRs) bind to 3' untranslated regions of mRNA where they repress the translational step from mRNA to protein. Table 1 lists miRs implicated in chondrogenesis and hypertrophy and their targets.

Other publications have established whole sets of Runx2-regulating miRs (Zhang et al., 2011) as well as miRs involved in the decision between osteogenic and chondrogenic lineage (Suomi et al., 2008). Recently, the first mechano-inductive miR was discovered. In tension experiments, miR-365 was upregulated in chicken chondrocytes. MiR-365 was identified to target HDAC4 and to induce the expression of Ihh and collagen X (Guan et al., 2011). The mechanosensitivity of certain MiRs and HDACs (Li et al., 2011b) suggests an important role for epigenetics in mechanotransduction.

\section{MSC/Chondrocyte Co-Culture}

It has long been observed that the chondrogenic phenotype in differentiated limb bud mesenchymal cells is more stable when exposed to paracrine factors produced by mature chondrocytes (Solursh and Reiter, 1975). Co-culture of chondrocytes and adult stem cells (Fischer et al., 2010; Cooke et al., 2011; Acharya et al., 2012) in micromass pellet culture showed decreases in collagen X and MMP-13 expression compared to pellets containing stem cells alone. The combination of MSCs and chondrocytes in hyaluronic acid (HA) hydrogels at various ratios demonstrated decreases in collagen $\mathrm{X}$ expression with a MSC/ chondrocyte ratio of 4:1 (Bian et al., 2011a). This effect was lost when the two cell types were seeded in separate gels within the same well, indicating that some physical interaction may be necessary to realise suppression of hypertrophy. Conversely, micromass pellets with limited heterotypic cell-cell interactions by spatially arranging the two cell types by first pelleting MSCs and encapsulating them by adding an outer layer of chondrocytes, resulted in reduction of collagen X, Runx2, and MMP-13 expression (Cooke et al., 2011).

Many details as to the specifics of the heterotypic cell interactions remain unclear. However, PTHrPsecretion of chondrocytes was identified as responsible for the repression of collagen $\mathrm{X}$ in co-culture (Fischer et al., 2010). Studies have also shown collagen II matrix deposition in pellet co-culture originates exclusively from chondrocytes and not MSCs (Mo et al., 2009). These results point to mutual benefits for phenotype maintenance in both cell types - the presence of MSCs in co-cultures stimulates chondrocyte production of cartilage matrix, and chondrocytes seem to prevent or slow hypertrophy of differentiating MSCs. It is further possible that secreted factors from the MSCs or chondrocytes could be involved in epigenetic regulation of the other cell type by inducing or inhibiting the activity of DNA methyltransferases (Benton et al., 2009), HDACs or HATs.

\section{Biomaterials}

Chondrogenesis of MSCs has been shown to be induced and maintained by simply tailoring cell-matrix interactions

Table 1: MicroRNAs implied in hypertrophy of chondrocytes with their target.

\begin{tabular}{|c|c|c|c|c|}
\hline miR \# & Target & Species & Effect on hypertrophy & Reference \\
\hline $26 b$ & COL10A1, IGF-1 etc. & human MSC & inhibitory & (Han et al., 2010) \\
\hline 140 & ADAMTS-5 & mice & inhibitory & (Miyaki et al., 2010) \\
\hline 140 & HDAC4 & mice & stimulatory & (Tuddenham et al., 2006) \\
\hline $140-5 p$ & $\operatorname{Smad} 2 / 3$ & human $\mathrm{C}$ & stimulatory & (Swingler et al., 2011) \\
\hline 145 & Sox 9 & murine MSC & stimulatory & (Yang et al., 2011) \\
\hline 152 & $\begin{array}{l}\text { COL2, }-4,-6 \mathrm{~A} 1, \\
\text { BMP3 }\end{array}$ & human MSC & stimulatory & (Han et al., 2010) \\
\hline $199 *$ & Smad1 & murine MSC & stimulatory & (Lin et al., 2009) \\
\hline 204 & Runx2 & human MSC & inhibitory & (Huang et al., 2010) \\
\hline 365 & HDAC4 & chicken $\mathrm{C}$ & inhibitory & (Guan et al., 2011) \\
\hline $455-3 p$ & $\operatorname{Smad} 2 / 3$ & human C & stimulatory & (Swingler et al., 2011) \\
\hline 675 & COL2A1 repressor & human $\mathrm{C}$ & inhibitory & (Dudek et al., 2010) \\
\hline
\end{tabular}

Classification into miRs that inhibit or stimulate hypertrophy. Abbreviations: mesenchymal stem cell (MSC), chondrocyte $(\mathrm{C})$. 
(a)

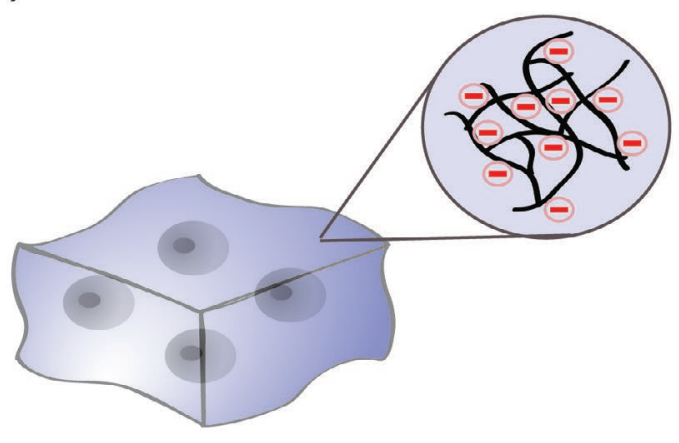

(b)

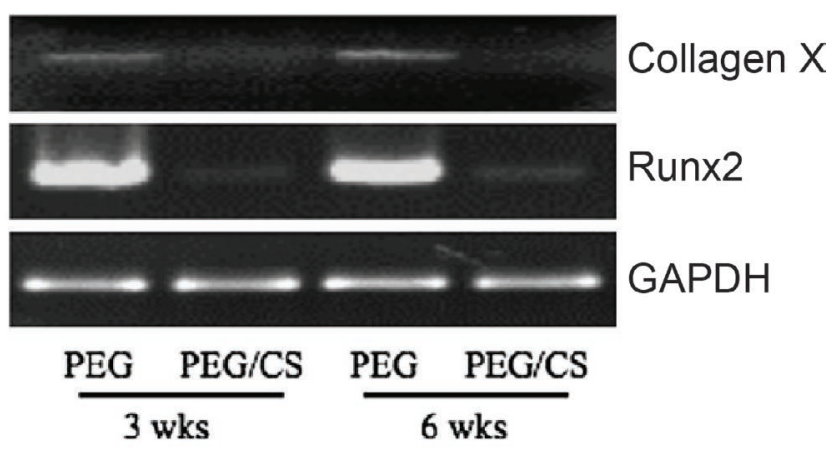

(c)

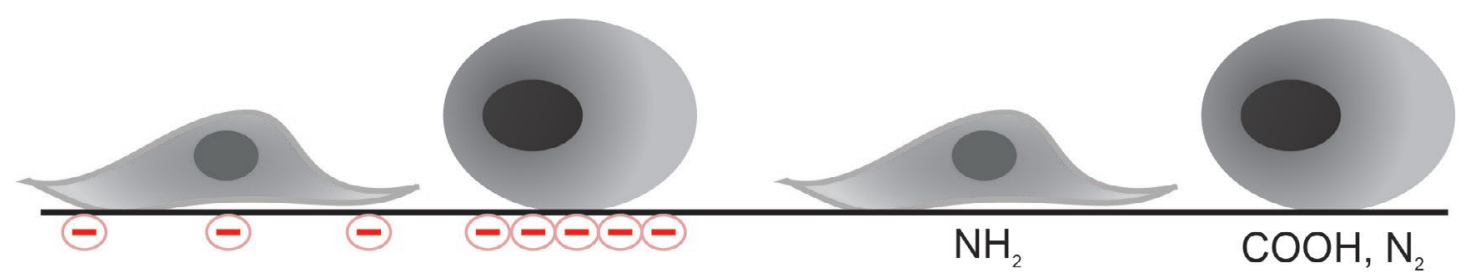

Fig. 5. Control of phenotype by cell-material interactions. (a) Cells encapsulated in hydrogels containing negatively charged chondroitin sulphate moieties exhibit (b) a significant decrease in their expression of hypertrophic markers Runx2 and collagen X. (c) Substrate modifications such as increasing charge density or surface functionalisation with carboxylate or $\mathrm{N}_{2}$-doped plasma promote the rounded phenotype associated with mature chondrocytes and also inhibit collagen X production. (b) is reprinted from (Varghese et al., 2008) with permission.

in a number of different scaffold and surface types including synthetic and natural polymer combinations (Awad et al., 2004; Betre et al., 2006; Park et al., 2011) as well as scaffolds from de-cellularised tissues (Choi et al., 2010). Surface functionalisation may further provide an important tool in arresting the chondrogenic phenotype prior to terminal differentiation of MSCs (Mwale et al., 2006; Woodfield et al., 2006).

Chondroitin sulphate (CS) and other nutraceuticals have long been postulated as being beneficial to joint health. MSC chondrogenesis in synthetic PEG hydrogels containing CS moieties (Fig. 5a) showed reduced collagen X mRNA and almost no Runx2 expression (Fig. 5b) compared to pure PEG gels (Varghese et al., 2008). However, another group explored a similar PEG/CS composite gel versus pure PEG gels but saw little difference in collagen $\mathrm{X}$ expression (Nguyen et al., 2010). These conflicting results indicate that the role of chondroitin sulphate in MSC differentiation is complex. The conformation and concentration of chondroitin sulphate within the hydrogel may influence its chondrogenic properties, particularly since sulphates have an affinity for growth factors such as TGF- $\beta$ (Re'em et al., 2011). Inclusion of the over-sulphated isoform of the marine polysaccharide GY785 DRS in chondrogenic induction media during pellet culture also results in reduced collagen X expression after 4 weeks in culture (Merceron et al., 2012). The relationship between sulphate groups and the growth factors involved in chondrogenesis has emerged as an intriguing one that should continue to be explored in future cartilage-engineering concepts.

Finally, de-cellularised tissues have been investigated as alternatives to synthetic scaffolds for regenerative medicine therapies (Hoshiba et al., 2010; Crapo et al., 2011; Song and Ott, 2011). Compared to polyglycolic acid (PGA) controls, MSCs seeded in de-cellularised porcine micromass pellet scaffolds were much slower to produce collagen $\mathrm{X}$ and did not attract vascularisation when implanted subcutaneously in nude mice (Choi et al., 2010).

Surface functionalisation is another important parameter dictating stem cell fate (Fig. 5c). Simply limiting the adhesion area was enough to switch MSC differentiation from the smooth muscle cell pathway to the chondrogenic pathway during cultivation in the presence of TGF- $\beta$ (Gao et al., 2010). In another study, increasing substrate charge density was shown to be beneficial for collagen II and aggrecan production in chondroprogenitor cells cultured in insulin-free media (Kwon et al., 2010). Glass surfaces modified with carboxyl (-COOH) functional groups produced higher quantities of collagen II and lower amounts of Runx 2 than controls or other functionalisation chemistries (Curran et al., 2005). Furthermore, it was shown that $\mathrm{N}$-doped plasma-polymerised ethylene surfaces containing $>30 \%$ nitrogen almost completely suppressed collagen X expression in MSCs cultured in growth media (Mwale et al., 2006). Generally, surface chemistries that promote a rounded cell morphology appear to be chondrogenic.

\section{Oxygen Tension}

Tissue engineering approaches have mostly involved expansion and differentiation of MSCs under normoxic conditions $\left(20 \% \mathrm{pO}_{2}\right)$; however, the in vivo MSC niche is hypoxic $\left(2-8 \% \mathrm{pO}_{2}\right)$ (Mohyeldin et al., 2010). Expansion 


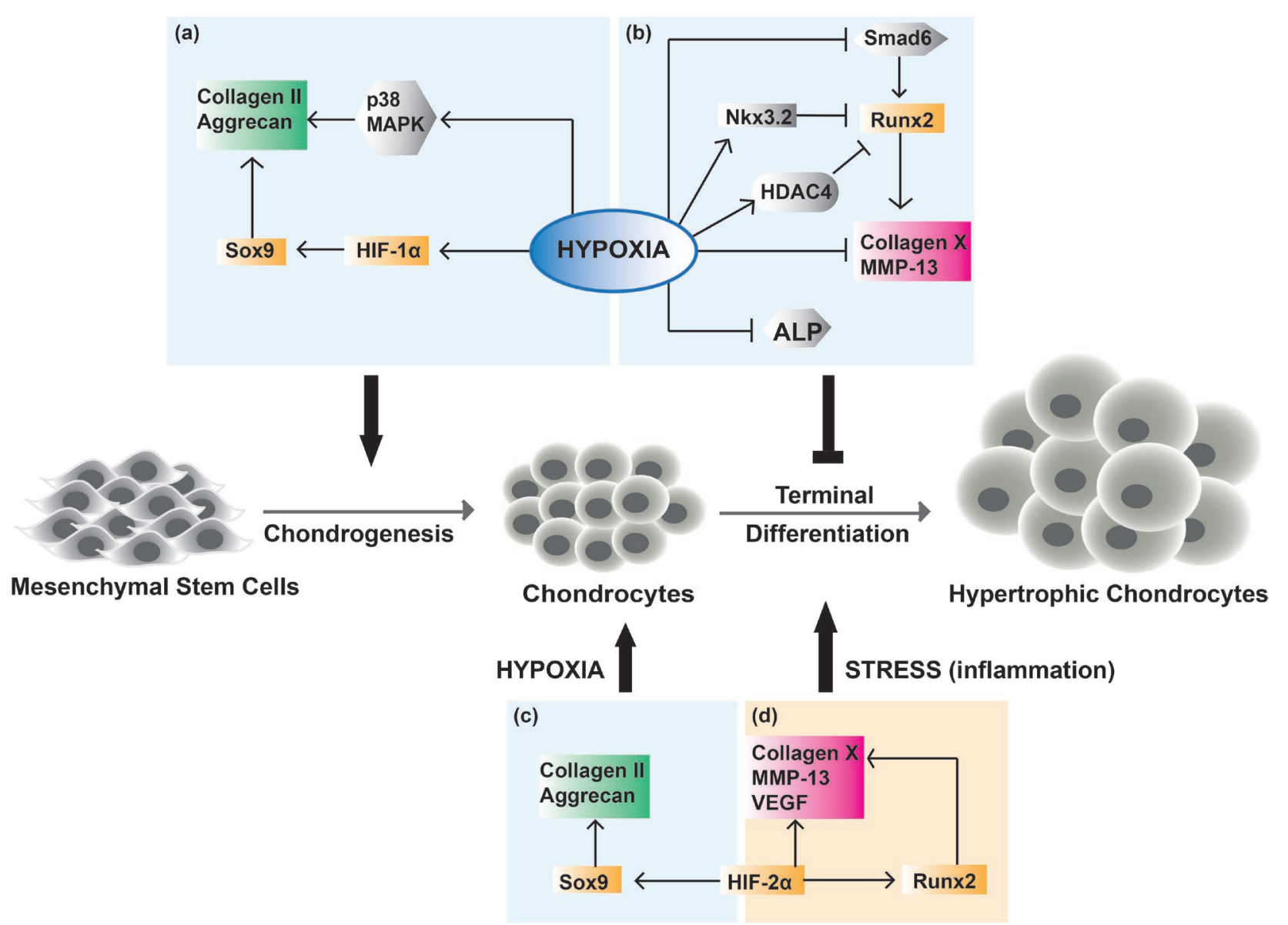

Fig. 6. Hypoxia regulates chondrogenic differentiation and hypertrophy. (a) Hypoxia enhances chondrogenesis of MSCs by up-regulating collagen II and aggrecan via activation of p38 MAPK pathway (Hirao et al., 2006) and HIF-1 $\alpha$-triggered Sox9 activity (Robins et al., 2005; Kanichai et al., 2008). (b) Subsequent chondrocyte hypertrophy is suppressed by hypoxia as shown by down-regulation of collagen X, MMP-13 and ALP (Ronziere et al., 2010; Sheehy et al., 2012). Hypoxic repression of hypertrophy is a combined effect of regulation through HDAC4 and Nkx3.2 activation as well as Smad6 inhibition, all resulting in the suppression of Runx2 and hence collagen X (Hirao et al., 2006; Kawato et al., 2011). (c) HIF-2 $\alpha$ is shown to be a chondrogenic factor supporting collagen II and aggrecan expression of human articular chondrocytes under hypoxic conditions (Murphy and Sambanis, 2001; Murphy and Polak, 2004; Lafont et al., 2007). (d) On the other hand, HIF-2 $\alpha$ also induces chondrocyte hypertrophy with collagen X, MMP-13 and VEGF as its transcriptional targets (Saito et al., 2010). Runx2 is up-regulated with HIF-2 $\alpha$ leading to further expression of these genes (Tamiya et al., 2008). HIF-2 $\alpha$ induction of this catabolic pathway is triggered by stresses such as inflammation making HIF-2 $\alpha$ a putative target for osteoarthritis (Saito et al., 2010; Yang et al., 2010).

under hypoxia was reported to enhance preservation of stemness properties (D'Ippolito et al., 2006; Grayson et al., 2006) and subsequent differentiation potential of bone marrow-derived MSCs in vitro (Lennon et al., 2001; Zscharnack et al., 2009). Expansion of adipose-derived human MSCs under hypoxic conditions suppressed the hypertrophic phenotype assessed by down-regulation of collagen X and MMP-13 (Ronziere et al., 2010). Suppression of MMP-13 and Runx2 were also observed for adipose-derived adult stromal cells due to hypoxic expansion conditions (Xu et al., 2007). Similarly, hypoxia enhanced chondro-specific differentiation of the MSC line C3H10T1/2 with collagen II and aggrecan up-regulation via p38 MAPK pathway (Fig. 6a) and suppressed hypertrophy by down-regulating collagen X through Runx2 inhibition (Hirao et al., 2006) (Fig. 6b). Despite induction of Runx 2 by p38 MAPK pathway, hypoxic maintenance of chondrogenic phenotype was stated to be a combined effect of HDAC4 induction, Smad6 pathway repression (Hirao et al., 2006) and Nkx3.2 up-regulation (Kawato et al., 2011) leading to overall down-regulation of Runx2 (Fig. $6 \mathrm{~b})$. Moreover, hypoxic differentiation of bone marrowderived MSCs in both pellets and hydrogels was revealed to suppress markers of hypertrophy such as collagen $\mathrm{X}$ and alkaline phosphatase (Sheehy et al., 2012) (Fig. 6b).

Two oxygen-sensitive transcription factors, hypoxiainducible factor 1 alpha and 2 alpha (HIF-1 $\alpha$ and HIF$2 \alpha$ ), have essential roles in the chondrogenic effect of hypoxia. HIF-1 $\alpha$ was shown to improve chondrogenesis of MSCs via inducing expression of collagen II through interaction with the Sox9 promoter (Robins et al., 2005; Kanichai et al., 2008) (Fig. 6a). Pellet culture of human articular chondrocytes under low oxygen tension yielded enhanced levels of collagen II, aggrecan and GAG as well 
Table 2: Target molecules for hypertrophy regulation.

\begin{tabular}{lll}
\hline & Hypertrophy Stimulators & Hypertrophy Inhibitors \\
\hline Transcription factors & Runx2 & Sox9 \\
& MEF2C & Nkx3.2 \\
Molecular signalling & Calcium, CaMKII, CaR & PTHrP \\
& Smad 1/5/8 & Smad 2/3 \\
& canonical Wnt & \\
& Integrin- $\beta 1$ & \\
Epigenetics & Collagen X demethylation & HDAC4 \\
Biomaterials & & Negatively-charged, carbohydrate-rich \\
Oxygen tension & & Low pO 2 \\
Co-culture & & Secreted PTHrP \\
\hline
\end{tabular}

as down-regulation of catabolic factors such as MMP-13. This chondrogenic and anti-catabolic effect of hypoxia was reported to disappear with the addition of an HIF$1 \alpha$ inhibitor (Ströbel et al., 2010). The role of HIF-2 $\alpha$ in chondrogenesis is currently debated (Murphy, 2010). Human articular chondrocytes demonstrated increased collagen II and aggrecan levels during redifferentiation under hypoxic conditions (Murphy and Sambanis, 2001; Murphy and Polak, 2004) where HIF-2 $\alpha /$ Sox 9 interactions were indicated to have a key role in the expression of these chondrogenic markers (Lafont et al., 2007) (Fig. 6c). In contrast, HIF-2 $\alpha$ was shown to be crucial for endochondral ossification processes such as hypertrophy, matrix degradation and vascularisation via direct transactivation of collagen X, MMP-13 and VEGF (Saito et al., 2010) (Fig. 6d). Similarly, expression of the HIF-2 $\alpha$-encoding gene Epas1 was reported to increase during differentiation of ATDC5 cells paralleling the increase in collagen X, MMP-13 and VEGF (Saito et al., 2010). Moreover, HIF-2 $\alpha$ was shown to enhance Runx 2 promoter activity bringing HIF- $2 \alpha$ further in the context of hypertrophy (Tamiya et al., 2008) (Fig. 6d). Linking oxygen tension and epigenetic regulation of hypertrophy, HIF-2 $\alpha$ signaling was interestingly shown to be promoted by Sirtuin 1, a redox-sensing deacetylase, under hypoxic conditions (Dioum et al., 2009). The significance of HIF$2 \alpha$ for cartilage tissue being obvious, whether it is a factor supporting chondrogenic phenotype or a catabolic regulator leading to hypertrophy remains an open question.

\section{Outlook}

Chondrocyte hypertrophy is controlled by a complex network of signalling molecules and biophysical factors that together present a wide range of possible targets for microenvironmental engineering (Table 2). The overexpression of HDAC4, stabilisation of HIFs for normoxic conditions, miRNA targeting, reducing extracellular calcium and incorporation of negatively charged carbohydrates into smart materials represent as yet unexplored avenues for stabilising the phenotype of MSCs which could be effectively used in skeletal regenerative medicine. These, in conjunction with the activation of antidifferentiation factors, perhaps produced by differentiated chondrocytes in the same repair site, could take us a few steps closer to the goal of stably controlling stem cell fate.

\section{Acknowledgements}

This study was supported by the Swiss National Science Foundation (CR23I2-130678/1) to MZW and KMW and the European Union Seventh Framework Programme (FP7/2007-2013) under grant agreement $n^{\circ}$ NMP4SL-2009-229292 (Find\&Bind). We acknowledge Markus Rottmar for carefully reviewing the manuscript.

\section{References}

Acharya C, Adesida A, Zajac P, Mumme M, Riesle J, Martin I, Barbero A (2012) Enhanced chondrocyte proliferation and mesenchymal stromal cells chondrogenesis in coculture pellets mediate improved cartilage formation. J Cell Physiol 227: 88-97.

Amano M, Chihara K, Kimura K, Fukata Y, Nakamura N, Matsuura Y, Kaibuchi K (1997) Formation of actin stress fibers and focal adhesions enhanced by Rho-kinase. Science 275: 1308-1311.

Amling M, Neff L, Tanaka S, Inoue D, Kuida K, Weir E, Philbrick WM, Broadus AE, Baron R (1997) Bcl-2 lies downstream of parathyroid hormone-related peptide in a signaling pathway that regulates chondrocyte maturation during skeletal development. J Cell Biol 136: 205-213.

Anderson HC (2003) Matrix vesicles and calcification. Curr Rheumatol Rep 5: 222-226.

Angers S, Moon RT (2009) Proximal events in Wnt signal transduction. Nat Rev Mol Cell Biol 10: 468-477.

Arnold MA, Kim Y, Czubryt MP, Phan D, McAnally J, Qi X, Shelton JM, Richardson JA, Bassel-Duby R, Olson EN (2007) MEF2C transcription factor controls chondrocyte hypertrophy and bone development. Dev Cell 12: 377-389.

Awad HA, Quinn Wickham M, Leddy HA, Gimble JM, Guilak F (2004) Chondrogenic differentiation of adiposederived adult stem cells in agarose, alginate, and gelatin scaffolds. Biomaterials 25: 3211-3222.

Backs J, Song K, Bezprozvannaya S, Chang S, Olson EN (2006) CaM kinase II selectively signals to histone 
deacetylase 4 during cardiomyocyte hypertrophy. J Clin Invest 116: 1853-1864.

Backs J, Backs T, Bezprozvannaya S, McKinsey TA, Olson EN (2008) Histone deacetylase 5 acquires calcium/calmodulin-dependent kinase II responsiveness by oligomerization with histone deacetylase 4 . Mol Cell Biol 28: 3437-3445.

Balcerzak M, Hamade E, Zhang L, Pikula S, Azzar G, Radisson J, Bandorowicz-Pikula J, Buchet R (2003) The roles of annexins and alkaline phosphatase in mineralization process. Acta Biochim Pol 50: 1019-1038.

Barry F, Boynton RE, Liu B, Murphy JM (2001) Chondrogenic differentiation of mesenchymal stem cells from bone marrow: differentiation-dependent gene expression of matrix components. Exp Cell Res 268: 189200.

Barter MJ, Bui C, Young DA (2012) Epigenetic mechanisms in cartilage and osteoarthritis: DNA methylation, histone modifications and microRNAs. Osteoarthritis Cartilage 20: 339-349.

Bassik MC, Scorrano L, Oakes SA, Pozzan T, Korsmeyer SJ (2004) Phosphorylation of BCL-2 regulates $\mathrm{ER} \mathrm{Ca}^{2+}$ homeostasis and apoptosis. EMBO J 23: $1207-$ 1216.

Bawden JW (1989) Calcium transport during mineralization. Anat Rec 224: 226-233.

Benton G, Crooke E, George J (2009) Laminin-1 induces E-cadherin expression in 3-dimensional cultured breast cancer cells by inhibiting DNA methyltransferase 1 and reversing promoter methylation status. Faseb J 23: 3884-3895.

Benya PD, Shaffer JD (1982) Dedifferentiated chondrocytes reexpress the differentiated collagen phenotype when cultured in agarose gels. Cell 30: 215-224.

Beris AE, Lykissas MG, Papageorgiou CD, Georgoulis AD (2005) Advances in articular cartilage repair. Injury 36: S14-S23.

Betre H, Ong SR, Guilak F, Chilkoti A, Fermor B, Setton LA (2006) Chondrocytic differentiation of human adipose-derived adult stem cells in elastin-like polypeptide. Biomaterials 27: 91-99.

Bian L, Zhai DY, Mauck RL, Burdick JA (2011a) Coculture of human mesenchymal stem cells and articular chondrocytes reduces hypertrophy and enhances functional properties of engineered cartilage. Tissue Eng Part A 17: $1137-1145$

Bian L, Zhai DY, Tous E, Rai R, Mauck RL, Burdick JA (2011b) Enhanced MSC chondrogenesis following delivery of TGF-beta3 from alginate microspheres within hyaluronic acid hydrogels in vitro and in vivo. Biomaterials 32: 6425-6434.

Bohrnsen F, Lindner U, Meier M, Gadallah A, Schlenke P, Lehnert H, Rohwedel J, Kramer J (2009) Murine mesenchymal progenitor cells from different tissues differentiated via mesenchymal microspheres into the mesodermal direction. Bmc Cell Biol 10: 92-107.

Bonen DK, Schmid TM (1991) Elevated extracellular calcium concentrations induce type $\mathrm{X}$ collagen synthesis in chondrocyte cultures. J Cell Biol 115: 1171-1178.

Bradley EW, Drissi MH (2010) WNT5A regulates chondrocyte differentiation through differential use of the CaN/NFAT and IKK/NF-kappa B pathways. Mol Endocrinol 24: 1581-1593.

Buckwalter JA, Mower D, Ungar R, Schaeffer J, Ginsberg B (1986) Morphometric analysis of chondrocyte hypertrophy. J Bone Joint Surg Am 68: 243-255.

Bush PG, Parisinos CA, Hall AC (2008) The osmotic sensitivity of rat growth plate chondrocytes in situ; Clarifying the mechanisms of hypertrophy. J Cell Physiol 214: 621-629.

Bush PG, Pritchard M, Loqman MY, Damron TA, Hall AC (2010) A key role for membrane transporter NKCC1 in mediating chondrocyte volume increase in the mammalian growth plate. J Bone Miner Res 25: 1594-1603.

Caporali E (2011) Impact of the DNA methyltransferase inhibitor, 5-azacytidine, on chondrocytic phenotype. In: Vet Clinical Medicine, University of Illinois, UrbanaChampaign.

Chang W, Tu C, Chen TH, Komuves L, Oda Y, Pratt SA, Miller S, Shoback D (1999) Expression and signal transduction of calcium-sensing receptors in cartilage and bone. Endocrinology 140: 5883-5893.

Chao PH, West AC, Hung CT (2006) Chondrocyte intracellular calcium, cytoskeletal organization, and gene expression responses to dynamic osmotic loading. Am J Physiol Cell Physiol 291: C718-725.

Chen ZX, Riggs AD (2011) DNA methylation and demethylation in mammals. J Biol Chem 286: 18347 18353.

Cheung KS, Hashimoto K, Yamada N, Roach HI (2009) Expression of ADAMTS-4 by chondrocytes in the surface zone of human osteoarthritic cartilage is regulated by epigenetic DNA de-methylation. Rheumatol Int 29: 525-534.

Choi K-H, Choi BH, Park SR, Kim BJ, Min B-H (2010) The chondrogenic differentiation of mesenchymal stem cells on an extracellular matrix scaffold derived from porcine chondrocytes. Biomaterials 31: 5355-5365.

Choi SW, Jeong DU, Kim JA, Lee B, Joeng KS, Long F, Kim DW (2012) Indian Hedgehog signalling triggers Nkx3.2 protein degradation during chondrocyte maturation. Biochem J 443: 789-798.

Clark AL, Votta BJ, Kumar S, Liedtke W, Guilak F (2010) Chondroprotective role of the osmotically sensitive ion channel transient receptor potential vanilloid 4: ageand sex-dependent progression of osteoarthritis in Trpv4deficient mice. Arthritis Rheum 62: 2973-2983.

Connelly JT, Garcia AJ, Levenston ME (2008) Interactions between integrin ligand density and cytoskeletal integrity regulate BMSC chondrogenesis. J Cell Physiol 217: 145-154.

Cooke ME, Allon AA, Cheng T, Kuo AC, Kim HT, Vail TP, Marcucio RS, Schneider RA, Lotz JC, Alliston T (2011) Structured three-dimensional co-culture of mesenchymal stem cells with chondrocytes promotes chondrogenic differentiation without hypertrophy. Osteoarthritis Cartilage 19: 1210-1218.

Crapo PM, Gilbert TW, Badylak SF (2011) An overview of tissue and whole organ decellularization processes. Biomaterials 32: 3233-3243.

Curran J, Chen R, Hunt J (2005) Controlling the phenotype and function of mesenchymal stem cells in 
vitro by adhesion to silane-modified clean glass surfaces. Biomaterials 26: 7057-7067.

D’Andrea P, Calabrese A, Capozzi I, Grandolfo M, Tonon R, Vittur F (2000) Intercellular $\mathrm{Ca}^{2+}$ waves in mechanically stimulated articular chondrocytes. Biorheology 37: 75-83.

D'Ippolito G, Diabira S, Howard GA, Roos BA, Schiller PC (2006) Low oxygen tension inhibits osteogenic differentiation and enhances stemness of human MIAMI cells. Bone 39: 513-522.

Dioum EM, Chen R, Alexander MS, Zhang Q, Hogg RT, Gerard RD, Garcia JA (2009) Regulation of hypoxiainducible factor 2alpha signaling by the stress-responsive deacetylase sirtuin 1. Science 324: 1289-1293.

Dong Y-F, Soung DY, Schwarz EM, O’Keefe RJ, Drissi H (2006) Wnt induction of chondrocyte hypertrophy through the Runx2 transcription factor. J Cell Physiol 208: 77-86.

Dudek KA, Lafont JE, Martinez-Sanchez A, Murphy CL (2010) Type II collagen expression is regulated by tissue-specific miR-675 in human articular chondrocytes. J Biol Chem 285: 24381-24387.

Dy P, Wang W, Bhattaram P, Wang Q, Wang L, Ballock RT, Lefebvre V (2012) Sox9 directs hypertrophic maturation and blocks osteoblast differentiation of growth plate chondrocytes. Dev Cell 22: 597-609.

El-Serafi AT, Oreffo ROC, Roach HI (2011) Epigenetic modifiers influence lineage commitment of human bone marrow stromal cells: Differential effects of 5-azadeoxycytidine and trichostatin A. Differentiation 81: 35-41.

Elvenes J, Knutsen G, Johansen O, Moe BT, Martinez I (2009) Development of a new method to harvest chondroprogenitor cells from underneath cartilage defects in the knees. J Orthop Sci 14: 410-417.

Ezura Y, Sekiya I, Koga H, Muneta T, Noda M (2009) Methylation status of $\mathrm{CpG}$ islands in the promoter regions of signature genes during chondrogenesis of human synovium-derived mesenchymal stem cells. Arthritis Rheum 60: 1416-1426.

Farnum CE, Lee R, O’Hara K, Urban JP (2002) Volume increase in growth plate chondrocytes during hypertrophy: the contribution of organic osmolytes. Bone 30: 574-581.

Finan JD, Chalut KJ, Wax A, Guilak F (2009) Nonlinear osmotic properties of the cell nucleus. Ann Biomed Eng 37: 477-491.

Fischer J, Dickhut A, Rickert M, Richter W (2010) Human articular chondrocytes secrete parathyroid hormonerelated protein and inhibit hypertrophy of mesenchymal stem cells in coculture during chondrogenesis. Arthritis Rheum 62: 2696-2706.

Fosang AJ, Last K, Knäuper V, Murphy G, Neame PJ (1996) Degradation of cartilage aggrecan by collagenase-3 (MMP-13). Febs Letters 380: 17-20.

Freed LE, Guilak F, Guo XE, Gray ML, Tranquillo R, Holmes JW, Radisic M, Sefton MV, Kaplan D, VunjakNovakovic G (2006) Advanced tools for tissue engineering: scaffolds, bioreactors, and signaling. Tissue Eng 12: 3285 3305.

Furumatsu T, Ozaki T (2010) Epigenetic regulation in chondrogenesis. Acta Med Okayama 64: 155-161.
Furumatsu T, Tsuda M, Taniguchi N, Tajima Y, Asahara $\mathrm{H}$ (2005) Smad3 induces chondrogenesis through the activation of SOX9 via CREB-binding protein/p300 recruitment. J Biol Chem 280: 8343-8350.

Gao L, McBeath R, Chen CS (2010) Stem cell shape regulates a chondrogenic versus myogenic fate through Rac1 and N-cadherin. Stem Cells 28: 564-572.

Giannoni P, Narcisi R (2009) Nano-approaches in cartilage repair. J Appl Biomater Biomech 7: 1-12.

Grandolfo M, D'Andrea P, Martina M, Ruzzier F, Vittur F (1992) Calcium-activated potassium channels in chondrocytes. Biochem Biophys Res Commun 182: 14291434.

Grayson WL, Zhao F, Izadpanah R, Bunnell B, Ma T (2006) Effects of hypoxia on human mesenchymal stem cell expansion and plasticity in 3D constructs. J Cell Physiol 207: 331-339.

Guan Y-J, Yang X, Wei L, Chen Q (2011) MiR-365: a mechanosensitive microRNA stimulates chondrocyte differentiation through targeting histone deacetylase 4 . Faseb J 25: 4457-4466.

Guilak F, Zell RA, Erickson GR, Grande DA, Rubin CT, McLeod KJ, Donahue HJ (1999) Mechanically induced calcium waves in articular chondrocytes are inhibited by gadolinium and amiloride. J Orthop Res 17: 421-429.

Guo J, Chung UI, Kondo H, Bringhurst FR, Kronenberg HM (2002) The PTH/PTHrP receptor can delay chondrocyte hypertrophy in vivo without activating phospholipase C. Dev Cell 3: 183-194.

Hall BK, Miyake T (2000) All for one and one for all: condensations and the initiation of skeletal development. Bioessays 22: 138-147.

Han J, Yang T, Gao J, Wu J, Qiu X, Fan Q, Ma B (2010) Specific microRNA expression during chondrogenesis of human mesenchymal stem cells. Int J Mol Med 25: $377-$ 384.

Haudenschild DR, Chen J, Pang N, Lotz MK, D'Lima DD (2010) Rho kinase-dependent activation of SOX9 in chondrocytes. Arthritis Rheum 62: 191-200.

He HL, Lam M, McCormick TS, Distelhorst CW (1997) Maintenance of calcium homeostasis in the endoplasmic reticulum by bcl-2. J Cell Biol 138: 1219-1228.

Hellingman C, Blaney Davidson E, Koevoet W, Vitters E, van den Berg W, van Osch G, van der Kraan P (2011) Smad signaling determines chondrogenic differentiation of bone-marrow-derived mesenchymal stem cells: Inhibition of Smad1/5/8P prevents terminal differentiation and calcification. Tissue Eng Part A 17: 1157-1167.

Hendy GN, Guarnieri V, Canaff L (2009) Calciumsensing receptor and associated diseases. Prog Mol Biol Transl Sci 89: 31-95.

Hirao M, Tamai N, Tsumaki N, Yoshikawa H, Myoui A (2006) Oxygen tension regulates chondrocyte differentiation and function during endochondral ossification. J Biol Chem 281: 31079-31092.

Hirsch MS, Lunsford LE, Trinkaus-Randall V, Svoboda KK (1997) Chondrocyte survival and differentiation in situ are integrin mediated. Dev Dyn 210: 249-263.

Hoffmann A, Czichos S, Kaps C, Bachner D, Mayer H, Kurkalli BG, Zilberman Y, Turgeman G, Pelled G, Gross G, 
Gazit D (2002) The T-box transcription factor Brachyury mediates cartilage development in mesenchymal stem cell line C3H10T1/2. J Cell Sci 115: 769-781.

Holtzer H (1964) Control of chondrogenesis in the embryo. Biophys J 4: 239-250.

Hoshiba T, Lu H, Kawazoe N, Chen G (2010) Decellularized matrices for tissue engineering. Expert Opin Biol Ther 10: 1717-1728.

Huang J, Zhao L, Xing L, Chen D (2010) MicroRNA-204 regulates Runx 2 protein expression and mesenchymal progenitor cell differentiation. Stem Cells 28: 357-364.

Huang WD, Zhou X, Lefebvre V, De Crombrugghe B (2000) Phosphorylation of SOX9 by cyclic AMPdependent protein kinase A enhances SOX9's ability to transactivate a Col2a1 chondrocyte-specific enhancer (vol 20, pg 4149, 2000). Mol Cell Biol 20: 7838-7838.

Hunziker EB, Kapfinger E, Saager C (1999) Hypertrophy of growth plate chondrocytes in vivo is accompanied by modulations in the activity state and surface area of their cytoplasmic organelles. Histochem Cell Biol 112: 115-123.

Hutmacher DW (2000) Scaffolds in tissue engineering bone and cartilage. Biomaterials 21: 2529-2543.

Iannotti JP, Brighton CT (1989) Cytosolic ionized calcium-concentration in isolated chondrocytes from each zone of the growth plate. J Orthop Res 7: 511-518.

Iannotti JP, Naidu S, Noguchi Y, Hunt RM, Brighton CT (1994) Growth plate matrix vesicle biogenesis. The role of intracellular calcium. Clin Orthop Relat Res 306: 222-229.

Im GI, Lee JM, Kim HJ (2011) Wnt inhibitors enhance chondrogenesis of human mesenchymal stem cells in a long-term pellet culture. Biotechnol Lett 33: 1061-1068.

Inada M, Wang YM, Byrne MH, Rahman MU, Miyaura C, Lopez-Otin C, Krane SM (2004) Critical roles for collagenase-3 (Mmp13) in development of growth and in endochondral plate cartilage ossification. Proc Natl Acad Sci U S A 101: 17192-17197.

Jensen ED, Gopalakrishnan R, Westendorf JJ (2009) Bone morphogenic protein 2 activates protein kinase $\mathrm{D}$ to regulate histone deacetylase 7 localization and repression of Runx2. J Biol Chem 284: 2225-2234.

Johnson KA, Rose DM, Terkeltaub RA (2008) Factor XIIIA mobilizes transglutaminase 2 to induce chondrocyte hypertrophic differentiation. J Cell Sci 121: 2256-2264.

Johnstone B, Hering TM, Caplan AI, Goldberg VM, Yoo JU (1998) In vitro chondrogenesis of bone marrowderived mesenchymal progenitor cells. Exp Cell Res 238: 265-272.

Kafienah W, Mistry S, Dickinson SC, Sims TJ, Learmonth I, Hollander AP (2007) Three-dimensional cartilage tissue engineering using adult stem cells from osteoarthritis patients. Arthritis Rheum 56: 177-187.

Kang JS, Alliston T, Delston R, Derynck R (2005) Repression of Runx 2 function by TGF-[beta] through recruitment of class II histone deacetylases by Smad3. EMBO J 24: 2543-2555.

Kanichai M, Ferguson D, Prendergast PJ, Campbell VA (2008) Hypoxia promotes chondrogenesis in rat mesenchymal stem cells: a role for AKT and hypoxiainducible factor (HIF)-1alpha. J Cell Physiol 216: 708-715.
Kawato Y, Hirao M, Ebina K, Tamai N, Shi K, Hashimoto J, Yoshikawa H, Myoui A (2011) Nkx3.2induced suppression of Runx 2 is a crucial mediator of hypoxia-dependent maintenance of chondrocyte phenotypes. Biochem Biophys Res Commun 416: 205-210.

Kim YJ, Kim HJ, Im GI (2008) PTHrP promotes chondrogenesis and suppresses hypertrophy from both bone marrow-derived and adipose tissue-derived MSCs (vol 373, pg 104, 2008). Biochem Biophys Res Commun 376: $241-241$.

Kirsch T (2003) Annexins and tissue mineralization: Matrix vesicles, ion channel activity of annexins and annexin V/collagen interactions. In: Annexins (Bandorowicz-Pikula J, ed), Springer, New York/ Heidelberg, pp 172-181.

Kobayashi T, Chung UI, Schipani E, Starbuck M, Karsenty G, Katagiri T, Goad DL, Lanske B, Kronenberg HM (2002) PTHrP and indian hedgehog control differentiation of growth plate chondrocytes at multiple steps. Development 129: 2977-2986.

Kozhemyakina E, Cohen T, Yao TP, Lassar AB (2009) Parathyroid hormone-related peptide represses chondrocyte hypertrophy through a protein phosphatase 2A/histone deacetylase 4/MEF2 pathway. Mol Cell Biol 29: $5751-5762$.

Kronenberg HM (2006) PTHrP and skeletal development. Ann N Y Acad Sci 1068: 1-13.

Kuo CK, Li WJ, Mauck RL, Tuan RS (2006) Cartilage tissue engineering: its potential and uses. Curr Opin Rheumatol 18: 64-73.

Kwon HJ, Yasuda K, Ohmiya Y, Honma K, Chen YM, Gong JP (2010) In vitro differentiation of chondrogenic ATDC5 cells is enhanced by culturing on synthetic hydrogels with various charge densities. Acta Biomater 6: 494-501.

Kwon TG, Zhao X, Yang Q, Li Y, Ge CX, Zhao GS, Franceschi RT (2011) Physical and functional interactions between Runx2 and HIF-1 alpha induce vascular endothelial growth factor gene expression. J Cell Biochem 112: 3582-3593.

Lafont JE, Talma S, Murphy CL (2007) Hypoxiainducible factor 2alpha is essential for hypoxic induction of the human articular chondrocyte phenotype. Arthritis Rheum 56: 3297-3306.

Lamprecht SA, Lipkin M (2003) Chemoprevention of colon cancer by calcium, vitamin D and folate: molecular mechanisms. Nat Rev Cancer 3: 601-614.

Lanske B, Karaplis AC, Lee K, Luz A, Vortkamp A, Pirro A, Karperien M, Defize LH, Ho C, Mulligan RC, Abou-Samra AB, Juppner H, Segre GV, Kronenberg HM (1996) PTH/PTHrP receptor in early development and Indian hedgehog-regulated bone growth. Science 273: 663-666.

Lee J-M, Im G-I (2012) PTHrP isoforms have differing effect on chondrogenic differentiation and hypertrophy of mesenchymal stem cells. Biochem Biophys Res Commun 421: 819-824.

Lengner CJ, Hassan MQ, Serra RW, Lepper C, van Wijnen AJ, Stein JL, Lian JB, Stein GS (2005) Nkx3.2mediated repression of Runx2 promotes chondrogenic differentiation. J Biol Chem 280: 15872-15879. 
Lennon DP, Edmison JM, Caplan AI (2001) Cultivation of rat marrow-derived mesenchymal stem cells in reduced oxygen tension: effects on in vitro and in vivo osteochondrogenesis. J Cell Physiol 187: 345-355.

Li TF, Dong YF, Ionescu AM, Rosier RN, Zuscik MJ, Schwarz EM, O'Keefe RJ, Drissi H (2004) Parathyroid hormone-related peptide (PTHrP) inhibits Runx2 expression through the PKA signaling pathway. Exp Cell Res 299: 128-136.

Li WJ, Tuli R, Huang X, Laquerriere P, Tuan RS (2005) Multilineage differentiation of human mesenchymal stem cells in a three-dimensional nanofibrous scaffold. Biomaterials 26: 5158-5166.

Li Y, Ahrens MJ, Wu A, Liu J, Dudley AT (2011a) Calcium/calmodulin-dependent protein kinase II activity regulates the proliferative potential of growth plate chondrocytes. Development 138: 359-370.

Li Y, Chu JS, Kurpinski K, Li X, Bautista DM, Yang L, Sung KL, Li S (2011b) Biophysical regulation of histone acetylation in mesenchymal stem cells. Biophys $\mathrm{J}$ 100: 1902-1909.

Lin EA, Kong L, Bai XH, Luan Y, Liu CJ (2009) miR-199a*, a bone morphogenic protein 2-responsive microRNA, regulates chondrogenesis via direct targeting to Smad1. J Biol Chem 284: 11326-11335.

Liu SQ, Tian Q, Hedrick JL, Po Hui JH, Ee PL, Yang YY (2010) Biomimetic hydrogels for chondrogenic differentiation of human mesenchymal stem cells to neocartilage. Biomaterials 31: 7298-7307.

Loeser RF, Carlson CS, McGee MP (1995) Expression of beta 1 integrins by cultured articular chondrocytes and in osteoarthritic cartilage. Exp Cell Res 217: 248-257.

Loeser RF, Sadiev S, Tan L, Goldring MB (2000) Integrin expression by primary and immortalized human chondrocytes: evidence of a differential role for alpha 1 beta 1 and alpha 2 beta 1 integrins in mediating chondrocyte adhesion to types II and VI collagen. Osteoarthritis Cartilage 8: 96-105.

Lu ZF, Zandieh Doulabi B, Huang CL, Bank RA, Helder MN (2008) Betal integrins regulate chondrogenesis and rock signaling in adipose stem cells. Biochem Biophys Res Commun 372: 547-552.

Luckman SP, Rees E, Kwan AP (2003) Partial characterization of cell-type $\mathrm{X}$ collagen interactions. Biochem J 372: 485-493.

Mackay AM, Beck SC, Murphy JM, Barry FP, Chichester CO, Pittenger MF (1998) Chondrogenic differentiation of cultured human mesenchymal stem cells from marrow. Tissue Eng 4: 415-428.

Mackie EJ, Tatarczuch L, Mirams M (2011) The skeleton: a multi-functional complex organ: the growth plate chondrocyte and endochondral ossification. J Endocrinol 211: 109-121.

Macrae VE, Davey MG, McTeir L, Narisawa S, Yadav MC, Millan JL, Farquharson C (2010) Inhibition of PHOSPHO1 activity results in impaired skeletal mineralization during limb development of the chick. Bone 46: 1146-1155.

Mak KK, Kronenberg HM, Chuang PT, Mackem S, Yang YZ (2008) Indian hedgehog signals independently of
PTHrP to promote chondrocyte hypertrophy. Development 135: 1947-1956.

Maruyama T, Mirando AJ, Deng CX, Hsu W (2010) The balance of WNT and FGF signaling influences mesenchymal stem cell fate during skeletal development. Sci Signal 3: ra40.

Mauck R, Burdick J (2011) Engineering cartilage tissue. In: Tissue Engineering (Pallua N, Suscheck CV, eds), Springer, Berlin Heidelberg, pp 493-520.

Mauck RL, Yuan X, Tuan RS (2006) Chondrogenic differentiation and functional maturation of bovine mesenchymal stem cells in long-term agarose culture. Osteoarthritis Cartilage 14: 179-189.

Mello MA, Tuan RS (1999) High density micromass cultures of embryonic limb bud mesenchymal cells: an in vitro model of endochondral skeletal development. In Vitro Cell Dev Biol Anim 35: 262-269.

Merceron C, Portron S, Vignes-Colombeix C, Rederstorff E, Masson M, Lesoeur J, Sourice S, Sinquin C, Colliec-Jouault S, Weiss P, Vinatier C, Guicheux J (2012) Pharmacological modulation of human mesenchymal stem cell chondrogenesis by a chemically oversulfated polysaccharide of marine origin: potential application to cartilage regenerative medicine. Stem Cells 30: 471-480.

Millward-Sadler SJ, Salter DM (2004) Integrin-dependent signal cascades in chondrocyte mechanotransduction. Ann Biomed Eng 32: 435-446.

Miyaki S, Sato T, Inoue A, Otsuki S, Ito Y, Yokoyama S, Kato Y, Takemoto F, Nakasa T, Yamashita S, Takada S, Lotz MK, Ueno-Kudo H, Asahara H (2010) MicroRNA-140 plays dual roles in both cartilage development and homeostasis. Gene Dev 24: 1173-1185.

Mo XT, Guo SC, Xie HQ, Deng L, Zhi W, Xiang Z, Li XQ, Yang ZM (2009) Variations in the ratios of co-cultured mesenchymal stem cells and chondrocytes regulate the expression of cartilaginous and osseous phenotype in alginate constructs. Bone 45: 42-51.

Mohyeldin A, Garzon-Muvdi T, Quinones-Hinojosa A (2010) Oxygen in stem cell biology: a critical component of the stem cell niche. Cell Stem Cell 7: 150-161.

Mrugala D, Dossat N, Ringe J, Delorme B, Coffy A, Bony C, Charbord P, Haupl T, Daures JP, Noel D, Jorgensen C (2009) Gene expression profile of multipotent mesenchymal stromal cells: Identification of pathways common to TGFbeta3/BMP2-induced chondrogenesis. Cloning Stem Cells 11: 61-76.

Mueller MB, Tuan RS (2008) Functional characterization of hypertrophy in chondrogenesis of human mesenchymal stem cells. Arthritis Rheum 58: 1377-1388.

Murphy CL (2010) HIF-2 alpha - a mediator of osteoarthritis? Cell Res 20: 977-979.

Murphy CL, Polak JM (2004) Control of human articular chondrocyte differentiation by reduced oxygen tension. J Cell Physiol 199: 451-459.

Murphy CL, Sambanis A (2001) Effect of oxygen tension and alginate encapsulation on restoration of the differentiated phenotype of passaged chondrocytes. Tissue Eng 7: 791-803.

Mwale F, Girard-Lauriault PL, Wang HT, Lerouge S, Antoniou J, Wertheimer MR (2006) Suppression of genes related to hypertrophy and osteogenesis in committed 
human mesenchymal stem cells cultured on novel nitrogenrich plasma polymer coatings. Tissue Eng 12: 2639-2647.

Narcisi R, Quarto R, Ulivi V, Muraglia A, Molfetta L, Giannoni P (2012) TGF beta-1 administration during ex-vivo expansion of human articular chondrocytes in a serum-free medium redirects the cell phenotype toward hypertrophy. J Cell Physiol 227: 3282-3290.

Negoro K, Kobayashi S, Takeno K, Uchida K, Baba $\mathrm{H}$ (2008) Effect of osmolarity on glycosaminoglycan production and cell metabolism of articular chondrocyte under three-dimensional culture system. Clin Exp Rheumatol 26: 534-541.

Nesic D, Whiteside R, Brittberg M, Wendt D, Martin I, Mainil-Varlet P (2006) Cartilage tissue engineering for degenerative joint disease. Adv Drug Deliv Rev 58: 300 322.

Nguyen LH, Kudva AK, Guckert NL, Linse KD, Roy K (2010) Unique biomaterial compositions direct bone marrow stem cells into specific chondrocytic phenotypes corresponding to the various zones of articular cartilage. Biomaterials 32: 1327-1338.

Orimo H (2010) The mechanism of mineralization and the role of alkaline phosphatase in health and disease. $\mathrm{J}$ Nihon Med Sch 77: 4-12.

Ortega N, Behonick DJ, Werb Z (2004) Matrix remodeling during endochondral ossification. Trends Cell Biol 14: 86-93.

Park SH, Choi BH, Park SR, Min BH (2011) Chondrogenesis of rabbit mesenchymal stem cells in fibrin/ hyaluronan composite scaffold in vitro. Tissue Eng Part A 17: 1277-1286.

Pei M, Chen DM, Li JT, Wei L(2009) Histone deacetylase 4 promotes TGF-beta 1 -induced synovium-derived stem cell chondrogenesis but inhibits chondrogenically differentiated stem cell hypertrophy. Differentiation 78: 260-268.

Pelttari K, Winter A, Steck E, Goetzke K, Hennig T, Ochs BG, Aigner T, Richter W (2006) Premature induction of hypertrophy during in vitro chondrogenesis of human mesenchymal stem cells correlates with calcification and vascular invasion after ectopic transplantation in SCID mice. Arthritis Rheum 54: 3254-3266.

Pittenger MF, Mackay AM, Beck SC, Jaiswal RK, Douglas R, Mosca JD, Moorman MA, Simonetti DW, Craig S, Marshak DR (1999) Multilineage potential of adult human mesenchymal stem cells. Science 284: 143-147.

Provot S, Kempf H, Murtaugh LC, Chung UI, Kim DW, Chyung J, Kronenberg HM, Lassar AB (2006) Nkx3.2/Bapx1 acts as a negative regulator of chondrocyte maturation. Development 133: 651-662.

Quintana L, Zur Nieden NI, Semino CE (2008) Morphogenetic and regulatory mechanisms during developmental chondrogenesis: new paradigms for cartilage tissue engineering. Tissue Eng Part B Rev 15: 29-41.

Re'em T, Kaminer-Israeli Y, Ruvinov E, Cohen S (2011) Chondrogenesis of hMSC in affinity-bound TGFbeta scaffolds. Biomaterials 33: 751-761.

Reddi AH (2000) Morphogenesis and tissue engineering of bone and cartilage: inductive signals, stem cells, and biomimetic biomaterials. Tissue Eng 6: 351-359.
Richter K, Nessling M, Lichter P (2007) Experimental evidence for the influence of molecular crowding on nuclear architecture. J Cell Sci 120: 1673-1680.

Roach HI, Yamada N, Cheung KSC, Tilley S, Clarke NMP, Oreffo ROC, Kokubun S, Bronner F (2005) Association between the abnormal expression of matrixdegrading enzymes by human osteoarthritic chondrocytes and demethylation of specific $\mathrm{CpG}$ sites in the promoter regions. Arthritis Rheum 52: 3110-3124.

Robins JC, Akeno N, Mukherjee A, Dalal RR, Aronow BJ, Koopman P, Clemens TL (2005) Hypoxia induces chondrocyte-specific gene expression in mesenchymal cells in association with transcriptional activation of Sox 9. Bone 37: 313-322.

Rodriguez L, Cheng ZQ, Chen TH, Tu CL, Chang WH (2005) Extracellular calcium and parathyroid hormonerelated peptide signaling modulate the pace of growth plate chondrocyte differentiation. Endocrinology 146: 4597-4608.

Ronziere MC, Perrier E, Mallein-Gerin F, Freyria AM (2010) Chondrogenic potential of bone marrow- and adipose tissue-derived adult human mesenchymal stem cells. Biomed Mater Eng 20: 145-158.

Saito T, Fukai A, Mabuchi A, Ikeda T, Yano F, Ohba S, Nishida N, Akune T, Yoshimura N, Nakagawa T, Nakamura K, Tokunaga K, Chung UI, Kawaguchi H (2010) Transcriptional regulation of endochondral ossification by HIF-2alpha during skeletal growth and osteoarthritis development. Nat Med 16: 678-686.

Sekiya I, Vuoristo JT, Larson BL, Prockop DJ (2002) In vitro cartilage formation by human adult stem cells from bone marrow stroma defines the sequence of cellular and molecular events during chondrogenesis. Proc Natl Acad Sci USA 99: 4397-4402.

Shapiro IM, Adams CS, Freeman T, Srinivas V (2005) Fate of the hypertrophic chondrocyte: microenvironmental perspectives on apoptosis and survival in the epiphyseal growth plate. Birth Defects Res C Embryo Today 75: 330339.

Sheehy EJ, Buckley CT, Kelly DJ (2012) Oxygen tension regulates the osteogenic, chondrogenic and endochondral phenotype of bone marrow derived mesenchymal stem cells. Biochem Biophys Res Commun 417: 305-310.

Shen G (2005) The role of type X collagen in facilitating and regulating endochondral ossification of articular cartilage. Orthod Craniofac Res 8: 11-17.

Shimizu E, Selvamurugan N, Westendorf JJ, Olson EN, Partridge NC (2010) HDAC4 represses matrix metalloproteinase-13 transcription in osteoblastic cells, and parathyroid hormone controls this repression. J Biol Chem 285: 9616-9626.

Solursh M, Reiter RS (1975) The enhancement of in vitro survival and chondrogenesis of limb bud cells by cartilage conditioned medium. Dev Biol 44: 278-287.

Song JJ, Ott HC (2011) Organ engineering based on decellularized matrix scaffolds. Trends Mol Med 17: 424-432.

Srinivas V, Bohensky J, Shapiro IM (2009) Autophagy: A new phase in the maturation of growth plate chondrocytes 
is regulated by HIF, mTOR and AMP kinase. Cells Tissues Organs 189: 88-92.

Stanton LA, Sabari S, Sampaio AV, Underhill TM, Beier F (2004) p38 MAP kinase signalling is required for hypertrophic chondrocyte differentiation. Biochem J 378: 53-62.

Ströbel S, Loparic M, Wendt D, Schenk AD, Candrian C, Lindberg RL, Moldovan F, Barbero A, Martin I (2010) Anabolic and catabolic responses of human articular chondrocytes to varying oxygen percentages. Arthritis Res Ther 12: R34.

Suomi S, Taipaleenmaki H, Seppanen A, Ripatti T, Vaananen K, Hentunen T, Saamanen AM, LaitalaLeinonen T (2008) MicroRNAs regulate osteogenesis and chondrogenesis of mouse bone marrow stromal cells. Gene Regul Syst Bio 2: 177-191.

Swieszkowski W, Tuan BH, Kurzydlowski KJ, Hutmacher DW (2007) Repair and regeneration of osteochondral defects in the articular joints. Biomol Eng 24: 489-495.

Swingler TE, Wheeler G, Carmont V, Elliott HR, Barter MJ, Abu-Elmagd M, Donell ST, Boot-Handford RP, Hajihosseini MK, Munsterberg A, Dalmay T, Young DA, Clark IM (2011) The expression and function of microRNAs in chondrogenesis and osteoarthritis. Arthritis Rheum 64: 1909-1919.

Takeda S, Bonnamy JP, Owen MJ, Ducy P, Karsenty G (2001) Continuous expression of Cbfa1 in nonhypertrophic chondrocytes uncovers its ability to induce hypertrophic chondrocyte differentiation and partially rescues Cbfa1deficient mice. Gene Dev 15: 467-481.

Tamiya H, Ikeda T, Jeong JH, Saito T, Yano F, Jung YK, Ohba S, Kawaguchi H, Chung UI, Choi JY (2008) Analysis of the Runx 2 promoter in osseous and non-osseous cells and identification of HIF2A as a potent transcription activator. Gene 416: 53-60.

Tanaka K, Yokosaki Y, Higashikawa F, Saito Y, Eboshida A, Ochi M (2007) The integrin alpha5beta1 regulates chondrocyte hypertrophic differentiation induced by GTP-bound transglutaminase 2. Matrix Biol 26: 409418.

Thirunavukkarasu K, Pei Y, Moore TL, Wei T, Wang H, Chandrasekhar S (2007) Regulation of NFATc2 gene expression by the transcription factor Runx2. Mol Biol Rep 34: 1-10.

Tomita M, Reinhold MI, Molkentin JD, Naski MC (2002) Calcineurin and NFAT4 induce chondrogenesis. J Biol Chem 277: 42214-42218.

Topol LL, Chen W, Song H, Day TF, Yang YZ (2009) Sox9 inhibits Wnt signaling by promoting beta-catenin phosphorylation in the nucleus. J Biol Chem 284: 3323 3333 .

Tuddenham L, Wheeler G, Ntounia-Fousara S, Waters J, Hajihosseini MK, Clark I, Dalmay T (2006) The cartilage specific microRNA-140 targets histone deacetylase 4 in mouse cells. Febs Letters 580: 4214-4217.

Van der Kraan PM, Davidson ENB, Blom A, van den Berg WB (2009) TGF-beta signaling in chondrocyte terminal differentiation and osteoarthritis Modulation and integration of signaling pathways through receptor-Smads. Osteoarthritis Cartilage 17: 1539-1545.
Van der Windt AE, Haak E, Kops N, Verhaar JA, Weinans H, Jahr H (2012) Inhibiting calcineurin activity under physiological tonicity elevates anabolic but suppresses catabolic chondrocyte markers. Arthritis Rheum 64: 1929-1939.

Van Donkelaar CC, Huiskes R (2007) The PTHrP-Ihh feedback loop in the embryonic growth plate allows PTHrP to control hypertrophy and Ihh to regulate proliferation. Biomech Model Mechan 6: 55-62.

Varghese S, Hwang NS, Canver AC, Theprungsirikul P, Lin DW, Elisseeff J (2008) Chondroitin sulfate based niches for chondrogenic differentiation of mesenchymal stem cells. Matrix Biol 27: 12-21.

Vega RB, Matsuda K, Oh J, Barbosa AC, Yang XL, Meadows E, McAnally J, Pomajzl C, Shelton JM, Richardson JA, Karsenty G, Olson EN (2004) Histone deacetylase 4 controls chondrocyte hypertrophy during skeletogenesis. Cell 119: 555-566.

Verzi MP, Agarwal P, Brown C, McCulley DJ, Schwarz JJ, Black BL (2007) The transcription factor MEF2C is required for craniofacial development. Dev Cell 12: 645652.

Vinatier C, Bouffi C, Merceron C, Gordeladze J, Brondello JM, Jorgensen C, Weiss P, Guicheux J, Noel D (2009) Cartilage tissue engineering: towards a biomaterialassisted mesenchymal stem cell therapy. Curr Stem Cell Res Ther 4: 318-329.

Vortkamp A, Lee K, Lanske B, Segre GV, Kronenberg HM, Tabin CJ (1996) Regulation of rate of cartilage differentiation by Indian hedgehog and PTH-related protein. Science 273: 613-622.

Wang AH, Bertos NR, Vezmar M, Pelletier N, Crosato M, Heng HH, Th'ng J, Han JH, Yang XJ (1999) HDAC4, a human histone deacetylase related to yeast HDA1, is a transcriptional corepressor. Mol Cell Biol 19: 7816-7827.

Wang F, Zhu Y (2011) Aquaporin-1: a potential membrane channel for facilitating the adaptability of rabbit nucleus pulposus cells to an extracellular matrix environment. J Orthop Sci 16: 304-312.

Wang GY, Woods A, Sabari S, Pagnotta L, Stanton LA, Beier F (2004) RhoA/ROCK signaling suppresses hypertrophic chondrocyte differentiation. J Biol Chem 279: 13205-13214.

Wang GY, Beier F (2005) Rac1/Cdc42 and RhoA GTPases antagonistically regulate chondrocyte proliferation, hypertrophy, and apoptosis. J Bone Miner Res 20: 1022-1031.

Weiss S, Hennig T, Bock R, Steck E, Richter W (2010) Impact of growth factors and PTHrP on early and late chondrogenic differentiation of human mesenchymal stem cells. J Cell Physiol 223: 84-93.

Wienholds E, Plasterk RH (2005) MicroRNA function in animal development. Febs Letters 579: 5911-5922.

Williams R, Khan IM, Richardson K, Nelson L, McCarthy HE, Analbelsi T, Singhrao SK, Dowthwaite GP, Jones RE, Baird DM, Lewis H, Roberts S, Shaw HM, Dudhia J, Fairclough J, Briggs T, Archer CW (2010) Identification and clonal characterisation of a progenitor cell sub-population in normal human articular cartilage. PLoS One 5: e13246. 
Woodfield TBF, Miot S, Martin I, van Blitterswijk CA, Riesle J (2006) The regulation of expanded human nasal chondrocyte re-differentiation capacity by substrate composition and gas plasma surface modification. Biomaterials 27: 1043-1053.

Woods A, Beier F (2006) RhoA/ROCK signaling regulates chondrogenesis in a context-dependent manner. J Biol Chem 281: 13134-13140.

Wu S, Palese T, Mishra OP, Delivoria-Papadopoulos M, De Luca F (2004) Effects of $\mathrm{Ca}^{2+}$ sensing receptor activation in the growth plate. Faseb J 18: 143-145.

Xu Y, Malladi P, Chiou M, Bekerman E, Giaccia AJ, Longaker MT (2007) In vitro expansion of adiposederived adult stromal cells in hypoxia enhances early chondrogenesis. Tissue Eng 13: 2981-2993.

Yamashita S, Andoh M, Ueno-Kudoh H, Sato T, Miyaki S, Asahara H (2009) Sox9 directly promotes Bapx1 gene expression to repress Runx 2 in chondrocytes. Exp Cell Res 315: 2231-2240.

Yang B, Guo H, Zhang Y, Chen L, Ying D, Dong S (2011) MicroRNA-145 regulates chondrogenic differentiation of mesenchymal stem cells by targeting Sox9. PLoS One 6: e21679.

Yang S, Kim J, Ryu JH, Oh H, Chun CH, Kim BJ, Min $\mathrm{BH}$, Chun JS (2010) Hypoxia-inducible factor-2 alpha is a catabolic regulator of osteoarthritic cartilage destruction. Nat Med 16: 687-693.

Yang X, Chen L, Xu XL, Li CL, Huang CF, Deng CX (2001) TGF-beta/Smad3 signals repress chondrocyte hypertrophic differentiation and are required for maintaining articular cartilage. J Cell Biol 153: 35-46.

Yoon BS, Pogue R, Ovchinnikov DA, Yoshii I, Mishina Y, Behringer RR, Lyons KM (2006) BMPs regulate multiple aspects of growth-plate chondrogenesis through opposing actions on FGF pathways. Development 133: 4667-4678.

Yoshida CA, Yamamoto H, Fujita T, Furuichi T, Ito K, Inoue KI, Yamana K, Zanma A, Takada K, Ito Y, Komori $\mathrm{T}$ (2004) Runx2 and Runx3 are essential for chondrocyte maturation, and Runx2 regulates limb growth through induction of Indian hedgehog. Gene Dev 18: 952-963.

Zhang Y, Xie RL, Croce CM, Stein JL, Lian JB, van Wijnen AJ, Stein GS (2011) A program of microRNAs controls osteogenic lineage progression by targeting transcription factor Runx2. Proc Natl Acad Sci U S A 108: 9863-9868.

Zhen XC, Wei L, Wu QQ, Zhang Y, Chen Q (2001) Mitogen-activated protein kinase $\mathrm{p} 38$ mediates regulation of chondrocyte differentiation by parathyroid hormone. J Biol Chem 276: 4879-4885.

Zhou G, Zheng QP, Engin F, Munivez E, Chen YQ, Sebald E, Krakow D, Lee B (2006) Dominance of SOX9 function over RUNX2 during skeletogenesis. Proc Natl Acad Sci USA 103: 19004-19009.
Zimmermann P, Boeuf S, Dickhut A, Boehmer S, Olek S, Richter W (2008) Correlation of COL10A1 induction during chondrogenesis of mesenchymal stem cells with demethylation of two $\mathrm{CpG}$ sites in the COL10A1 promoter. Arthritis Rheum 58: 2743-2753.

Zscharnack M, Poesel C, Galle J, Bader A (2009) Low oxygen expansion improves subsequent chondrogenesis of ovine bone-marrow-derived mesenchymal stem cells in collagen type I hydrogel. Cells Tissues Organs 190: 81-93.

Zuscik MJ, D’Souza M, Gunter KK, Gunter TE, O’Keefe RJ, Schwarz EM, Puzas JE, Rosier RN (2002) Growth plate chondrocyte maturation is regulated by basal intracellular calcium. Exp Cell Res 276: 310-319.

\section{Discussion with Reviewers}

Reviewer II: Is the expansion phase of MSCs relevant to determine the cell fate (hypertrophy)?

Authors: As is the case for chondrocyte expansion, the environmental conditions of MSC expansion are critical. One example is oxygen tension. In the study of Xu et al., expansion of adipose-derived adult stromal cells under low oxygen conditions has been reported to enhance the subsequent chondrogenic differentiation under ambient oxygen conditions. Chondrogenic markers such as collagen II and aggrecan were shown to increase whereas the level of hypertrophic markers MMP-13 and Runx2 decreased in response to expansion under hypoxia compared to normoxia. Moreover, osteogenic potential of the stem cells was shown to be suppressed by decreased levels of osteopontin and its receptor CD44 (Xu et al., 2007, additional reference). Ronziere et al. similarly showed that markers of hypertrophy such as collagen $\mathrm{X}$ and MMP-13 were suppressed due to expansion of adiposederived human MSCs under hypoxic conditions. Thus, the oxygen levels that stem cells are exposed to during their expansion phase seem to play a significant role in their further differentiation potential (Ronziere et al., 2010, additional reference).

\section{Additional References}

Ronziere MC, Perrier E, Mallein-Gerin F, Freyria AM (2010) Chondrogenic potential of bone marrow- and adipose tissue-derived adult human mesenchymal stem cells. Biomed Mater Eng 20: 145-158.

Xu Y, Malladi P, Chiou M, Bekerman E, Giaccia AJ, Longaker MT (2007) In vitro expansion of adiposederived adult stromal cells in hypoxia enhances early chondrogenesis. Tissue Eng 13: 2981-2993. 